Historic, Archive Document

Do not assume content reflects current scientific knowledge, policies, or practices. 



\section{Gob SAN FRANCISCO / CAL.}

\section{Fall Catalog of}
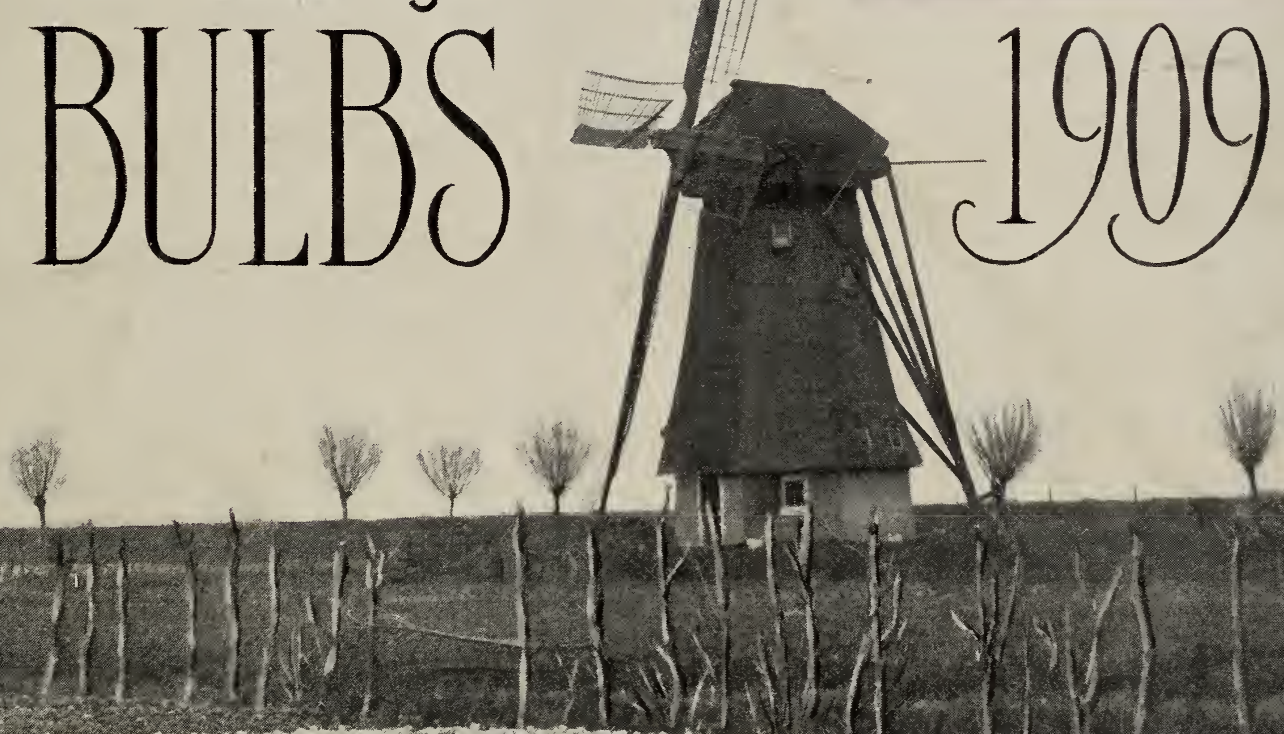

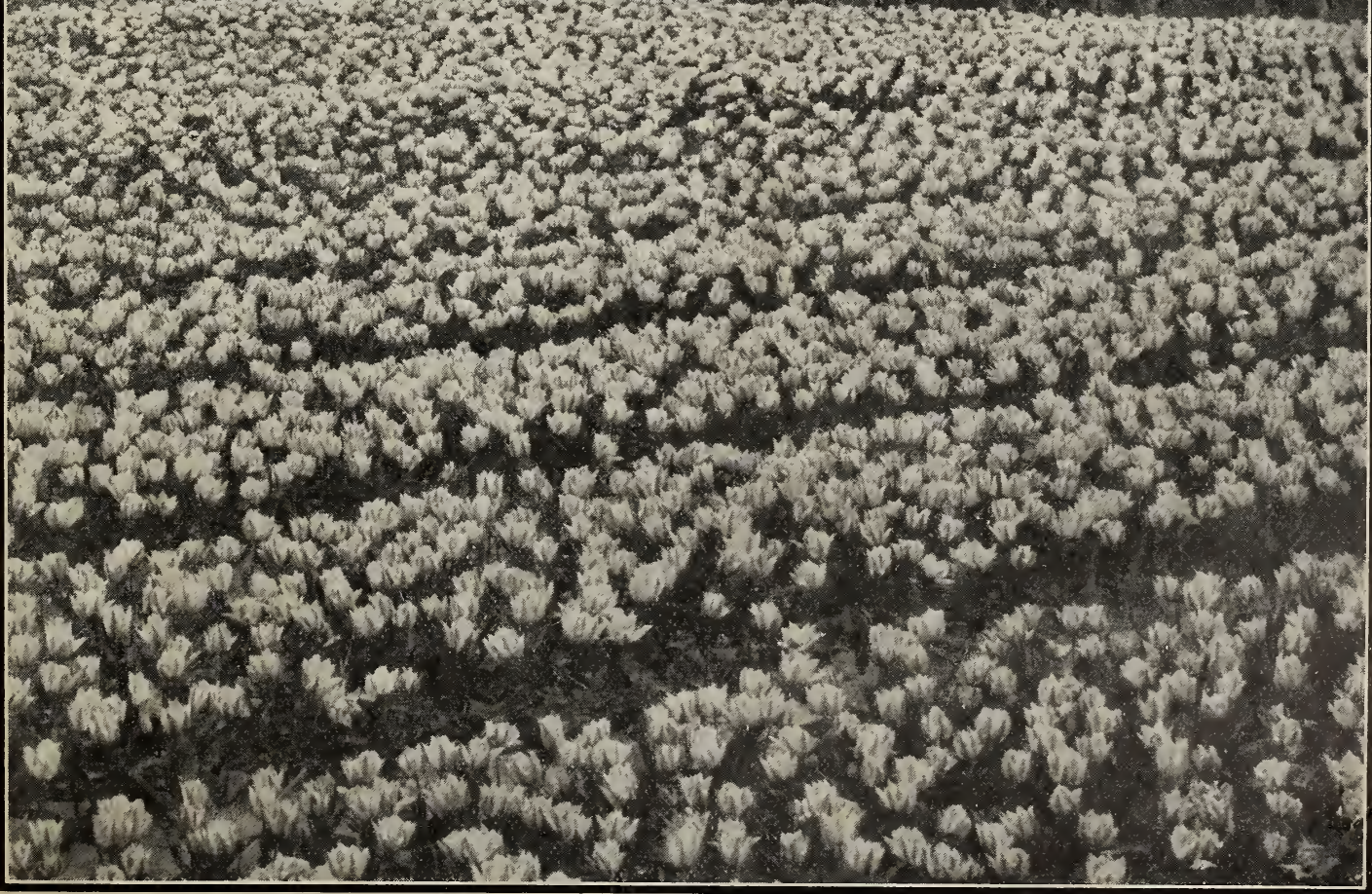




\section{C. MORSE \& CO'S}

CATALOGUE OF

BULBS

\section{and Seeds for Fall Planting}

\section{To Our Friends and Customers:}

In this, our third Fall Catalogue of Bulbs, we offer a finer and better selection of Dutch and'Japanese Bulbs than has ever before been offered on the Pacific Coast. Our prices we have altered so that, taking the heavy express charges into account, we believe them to be equal, if not lower, than all others.

Our stock is from the very best growers and is imported by us direct from Holland and Japan, and is much superior in flowering qualities to any that is locally grown.

Two years ago we presented for the first time on the Coast Susiana Mourning Iris, and last year the Philippine Lily, both of which have become great favorites. This year we have as novelties a new fine Strawberry (see p. 16), a new yellow and white Daffodil, Victoria; several new Lilies; a Scarlet Freesia; and the finest collection of selected Late Tulips to be had in the country. These latter are listed on the inside of the back cover, and we direct your attention to them.

Thanking you for past favors, and soliciting your orders again this season, we remain,

Respectfully yours,

C. C. MORSE \& CO.

OUR GENERAL CATALOGUE with complete list of Seeds and Plants will be mailed free to those whose names are on our list, in December and January. Our catalogue is unusually handsome this year and contains much valuable information about planting in California, as well as listing, seed of all sorts, plants and fruit trees. We shall be glad to send this catalogue to all intending purchasers.

EVERY GARDEN NEEDS SOME BULBS; they come into bloom in spring before other flowers, and have a most delightful fragrance and the brightest colors, and are easy to grow. Plant a special bed of bulbs; that is the best way to grow them. There need be no failures if our culture directions are followed.

THE FINEST OUTDOOR DISPLAYS of the early spring months are from bulbs planted in the fall. We would particularly impress on the amateur that the tall, and not the spring, is the proper time to plant all kinds of flowering bulbs. The larger part of the bulbs offered in this catalogue reach us from Europe and elsewhere in September, and the sooner they are planted after that the greater will be the measure of success.

MORSE'S BULBS ARE SELECTED AND SUPERIOR; they are from the finest growers in Holland, Japan, France and other countries, and are much superior to all home grown bulbs. Morse's bulbs are sound and of first size, and we would warn intending purchasers against buying cheap, undersized stock: the difference in price is too little compared with the difference in results.

\section{Order Early}

ORDERS SHOULD BE SENT AS SOON AS POSSIBLE after receipt of this catalogue. Orders booked earliest are surest of being filled as ordered, because, if left too late, the supply of some of the varieties may be exhausted.

You are Invited to Visit Our Retail Store, 125-127 Market Street, San Francisco,

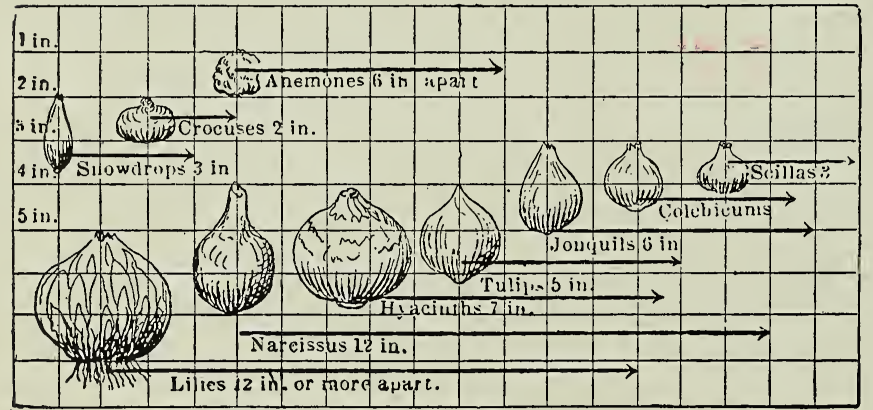

Depths at which bulbs should be planted.

and Inspect Our Bulbs and See the Many Colored Pictures of Them Which We Have to Show.

\section{GENERAL CULTURE DIRECTIONS}

\section{DEPTHS AT WHICH BULBS SHOULD BE PLANTED}

The accompanying diagram explains the proper depth to plant bulbs. Outdoor planting should be done early in the fall to secure healthy plants vigorous foliage and beautiful flowers.

\section{CULTURE IN THE OPEN GROUND}

The soil for most hardy bulbs should be sandy loam, and of a texture that will not retain stagnant water. Well rotted stable manure or bone meal should be thoroughly worked into the soil so that it will not come in direct contact with the bulbs. Most bulbs like rich food if properly applied, as the proper development, luxuriance and brilliancy depend largely upon the nutrition the roots are consuming. Liberal applications of manure water when the flowers are in bud produce cations of manure water when the flowers are in bud produce
magnificent results. The proper depth to plant is carefully indicated on diagram above and deserves careful study.

\section{CULTURE IN POTS}

The best potting soil for bulbs is composed of fibrous loam, leaf mold and river sand in equal proportions. The pots should be filled lightly and the bulb pressed into the soil so that its base is firmly fixed. As a general rule, the top of the bulb should just show above the surface soil when planted.
To encourage and promote root growth the pots should be buried out of doors to the depth of six inches and left there for five or six weeks. By that time the pots should be well filled with roots and may then be taken indoors. There the warmth will soon bring them into flower. Plenty of water should be applied and liquid manure is beneficial after the flower spikes appear.

\section{CULTURE IN GLASSES}

Although there are other bulbs used for this method of culture, large well-shaped single hyacinths are the best for this purpose. Place the bulb so that the base merely touches the water. Set the glasses in a cool, dark, airy place until the roots have reached the bottom of the glass, which should be in about six weeks' time. If then kept in a cool should be in about six weeks fime. room, they will produce very fine spikes and remain in bloom
a long time. As the water evaporates, fill up the glasses and a long time. As the water evaporates, fill up the glasses and
change the water entirely when needed to keep it sweet and clear. A small piece of charcoal placed in the water will prevent it from getting foul. 


\section{Hyacinths}

Hyacinths with ordinary care are sure to bloom, and their flowers have a heavy fragrance which is very pleasing. Hyacinths have a wide range of colors in blue, red, pink, yellowish tints, and white. They are needed in every garden.

For out-of-door growing, plant in November if possible, although firm bulbs will bloom well if set out much later. The proper depth to plant is shown on the opposite page; for bedding effects, set six inches apart. The soil should be made rich with a liberal mulching of manure, and sand should be added if the soil is heavy. After flowering, the bulbs should be dried and lifted in early summer, and very often they can be used again.

Add 12c per dozen for postage, if ordered by mail.

\section{HYACINTHS IN COLORS}

Except for specialists and fanciers, there is more demand for "assortments" of Hyacinths, grouped in colors, and to meet this demand we have secured a fine large stock of assorted colors

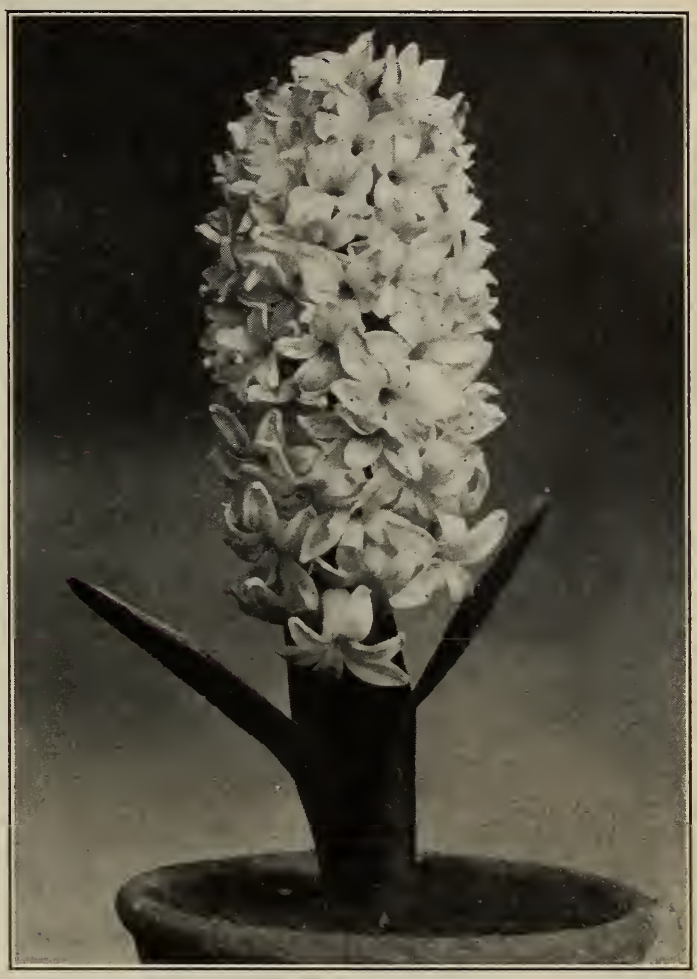

Type of Single Hyacinth as offered below. These come quite a little cheaper in price and can be afforded in larger quantities, and are therefore recommended for beds and borders. These bulbs are what the Dutch bulb growers call first size and are of the best quality.

\section{SINGLE VARIETIES}

\begin{tabular}{|c|c|c|}
\hline Light blue shades $\mathrm{mi}$ & .60 & $\$ 4.50$ \\
\hline Dark blue shades mixed. . . . . . . . . . & .60 & 4.50 \\
\hline Dark red shades mixed. . . & .60 & 4.50 \\
\hline Rose and pink shades mixed... & .60 & 4.50 \\
\hline White shades mixed. & 60 & 4.50 \\
\hline white shades mixed ..... & .60 & 4.50 \\
\hline w shades mixed..... & .65 & 4.75 \\
\hline red & .55 & 4.25 \\
\hline
\end{tabular}

\section{DOUBLE VARIETIES}

Light blue shades mixed....

Dark blue shades mixed.... .

Dark'red shades mixed....

Rose and pink shades mixed.

White shades mixed. .

Yellow shades mixed........

All colors mixed.
Per doz. Per 100

$\$ .60 \$ \$ 4.50$

$.60 \quad 4.50$

$.60 \quad 4.50$

$.60 \quad 4.50$

$.60 \quad 4.50$

$65 \quad 4.75$

$.55 \quad 4.25$

\section{NAMED VARIETIES OF HYACINTHS}

Extra large bulbs for flowering in glasses, and for growing outside.

\section{SINGLE BLUE}

\begin{tabular}{|c|c|c|c|}
\hline & \multicolumn{3}{|c|}{ Each Per doz. Per 100} \\
\hline $\begin{array}{l}\text { Czar Peter, } \\
\text { Fine porcelain blue... }\end{array}$ & $\$ .20$ & $\$ 2.00$ & $\$ 15.00$ \\
\hline $\begin{array}{l}\text { Grand Lilas, } \\
\text { Blue, lilac shaded.... }\end{array}$ & .15 & 1.50 & 12.00 \\
\hline $\begin{array}{l}\text { King of the Blues, } \\
\text { Dark blue......... }\end{array}$ & $\begin{array}{l}\cdot \\
. \quad 15\end{array}$ & 1.50 & 12.00 \\
\hline $\begin{array}{l}\text { Leonidas, } \\
\text { Light blue, large bells. }\end{array}$ & .12 & 1.25 & 10.00 \\
\hline
\end{tabular}

Masterpiece,

Very dark blue.

Marie,

Dark blue, fine spike. .

Queen of the Blues,

schotel,

Lavender, fine large spike.
Each Per doz. Per 100

$\begin{array}{rrr}\$ .25 & \$ 2.50 & \$ \ldots \\ .15 & 1.50 & 12.00 \\ .15 & 1.50 & 12.00 \\ \ldots .20 & 1.75 & 15.00\end{array}$




\section{Hyacinths- - continued}

\section{SINGLE WHITE}

Alba Superbissima,
White, large bells.

Each Per doz. Per 100

Baroness Van Thuyll,

White, small bells...

$\begin{array}{llll}. \$ & .15 & \$ 1.50 & \$ 12.00\end{array}$

Blanchard,

Early large, pure white.

$\begin{array}{lll}.15 & 1.50 \quad 12.00\end{array}$

L'Innocence,

Large truss of pure white.

Mont Blanc,

A splendid pure white.

Mammoth,

Blush white.

Voltaire,

Blush pink.

\section{SINGLE RED, ROSE AND PINK}

Each Per doz. Per 100

Amy

$\$ .10 \$ 1.00 \$ 8.00$

Cosmos

Dark pink, large spike. . . . . . . . . .15 $\quad \mathbf{1 . 5 0} \quad \mathbf{1 2 . 0 0}$

Fabiola,

Pink striped carmine. . . . . . . . $.12 \quad 125 \quad 10.00$

Gertrude,

Pink, very fine and popular. ...... $\quad .10 \quad 1000$

General Pelissier,

Deep crimson................ .15 $1.50 \quad 12.00$

Gigantea,

Pink, many flowerets........... $.15 \quad \mathbf{1 5} \quad \mathbf{1 . 5 0} \quad \mathbf{1 2 . 0 0}$

Homerus,

Reddish pink.

Robert steiger,

Deep crimson.

I'Amie du Coeur,

Carmine striped.

Roi des Belges,

Deep crimson scarlet.

\section{SINGLE YELLOW}

Bird of Paradise,

Beautiful citron yellow. . .

Herman,

Orange yellow.

Heroine,

Bright citron, yellow tips. .

King of the Yellows,

Golden yellow.

Sonora,

Buff color, tinted, large.
Each Per doz. Per 100

$\begin{array}{lll}\$ & .15 & \$ 1.50 \quad \$ 12.00\end{array}$

$\begin{array}{lll}.15 & 1.50 \quad 12.00\end{array}$

$\begin{array}{lll}.15 & 1.50 & 12.00\end{array}$

$\begin{array}{lll}.18 & 1.75 & 15.00\end{array}$

$\begin{array}{lll}.15 & 1.50 & 12.00\end{array}$

\section{DOUBLE RED}

Bouquet Tendre: deep carmine, good Czar Nicholas: light rose, very large.

Each Per doz. Per 100 Grootvoorst: delicate peach blossom.. $\begin{array}{lll}.15 & \$ 1.50 \quad \$ 12.00\end{array}$ Noble par Merite: deep rose..

$\begin{array}{lll}.12 & 1.25 & 10.00\end{array}$

$\begin{array}{lll}.15 & 1.50 \quad 12.00\end{array}$

$.151 .50 \quad 12.00$

\section{DOUBLE BLUE}

(1)

$\begin{array}{lll} & \\ \text { Each } & \text { Per doz. Per } 100 \\ \$ \$ \mathbf{1 5} & \mathbf{\$ 1 . 5 0} & \mathbf{\$ 1 2 . 0 0}\end{array}$

$\begin{array}{llll}\text { Mignon de Dryphout: light blue shaded } & \mathbf{. 1 2} & \mathbf{1 . 2 5} & \mathbf{1 0 . 0 0}\end{array}$

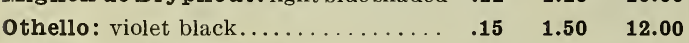

Prince of Saxe Weimar: dark blue, large spike.

\section{DOUBLE WHITE}

Each Per doz. Per 100

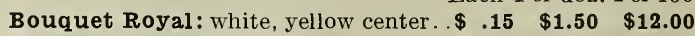

Grand Vainquer: pure white, fine.... $\quad .15 \quad 1.50 \quad 12.00$

La Tour D'Avergne: very large, pure

white................... $15 \quad 1.50 \quad 12.00$

La Virginite: blush white, very fine... $\quad .10, \quad 1.00 \quad 8.00$

Non Plus Ultra: blush pink........ $\quad .15 \quad 1.50 \quad 12.00$

Prince of Waterloo: pure white..... $\quad .15 \quad 1.50 \quad 12.00$

\section{DOUBLE YELLOW}

Each Per doz. Per 100

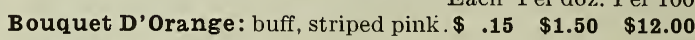

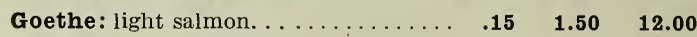

Minerva: range.................15 $1.50 \quad 12.00$

Jaune Supreme: deep yellow, good. . $\quad \begin{array}{llll}.15 & 1.50 & 12.00\end{array}$

\section{SPECIAL}

We will make up special assortments of named varieties, either our choice or yours, at the following rates: per dozen, $\$ 1.50$; per $100, \$ 10.00$.

\section{DUTCH ROMAN HYACINTHS}

\section{Known also as Minia ture Hyacinths}

These Hyacinths bear fewer bells than the others. The spikes are graceful and the flowers fragrant; they may be forced easily or grown out of doors. . $\ldots \ldots \ldots \ldots \ldots \ldots \ldots \ldots \ldots \ldots \ldots$

Creamy White. ................. 4 40 $\mathbf{3 . 0 0}$

Dark Red. . . . . . . . . . . . . . . . . . . $40 \quad 3.00$

Rosy Red.................... $40 \quad \mathbf{4 0}$

Dark Blue..................... $\mathbf{. 4 0} \quad \mathbf{3 . 0 0}$

Light Blue.................... .40 $\mathbf{3 0 0}$

All above colors mixed. . . . . . . . . . . .40 $\mathbf{4 0}$

\section{French Roman Hyacinths}

The flowers of this type, while smaller than the Dutch Hyacinth, are borne in much greater abundance, each bulb bearing several graceful flower spikes. They are especially fragrant and extremely early, also easily grown. If potted in August they can be brought into bloom in November and December, and a succession of flowers can be had throughout the season. For cutting purposes the French Roman Hyacinth is the finest bulb grown.

Pure white, large bulbs, 12 to 14 centimeters, each, 6c; per doz., 50c; per 100, \$3.75; extra select bulbs, 13 to 15 centimeters, each, 7c; per doz., 65c; per $100, \$ 5.00$.

\section{Grape and Feathered Hyacinths}

Grape. These are dainty little flower spikes bearing curious ball-shaped bells in white and blue. They are of the easiest culture and thrive either in sunny or partially shaded locations in the garden and can remain undisturbed for many years, multiplying their own roots as they grow older. Prices include postage.

Blue: $15 \mathrm{c}$ per doz.; $\$ 1.00$ per 100 .

White (Pearls of Spain): 20c per doz.; \$1.25 per 100.

Feathered (Muscari Plumosus), bears plume-like graceful spikes, 9 to 12 inches high, purple in color. 20c per doz.; $\$ 1.25$ per 100 . Postage, 5c per dozen additional. 


\section{Tulips}

Everyone who has planted our late flowering Tulips has had fine success with them. This is an unusual record for California and shows that the May flowering varieties are well adapted for out-of-door planting here. You need have no failure if you plant these sorts we recommend, but will be rewarded by the finest flowers in bright colors, clear yellow, dazzling red and shading from these to the dull reds which predominate the Darwin class of Tulips.

Tulips can be shown to advantage only in a bed. Don't plant only a dozen; plant a bed of fifty or more-they are worth it. Be sure to include some Gesneriana (page 3 of cover), the handsomest Scarlet Tulip.

\section{"MORSE'S SPECIAL TULIPS FOR} CALIFORNIA" are listed on the inside of the back cover. These and the Darwin and late Tulips on Page 4 are the long stemmed sorts we recommend. The back cover illustration is of Darwin Tulips. Please see what we say about them (inside page of back cover):

Enrich the soil liberally with manure, or dig a little bone meal under each bulb which is set on sand just above.

(If tulips are wanted by mail add 5 c per dozen; 25̃c per 100 for postage).

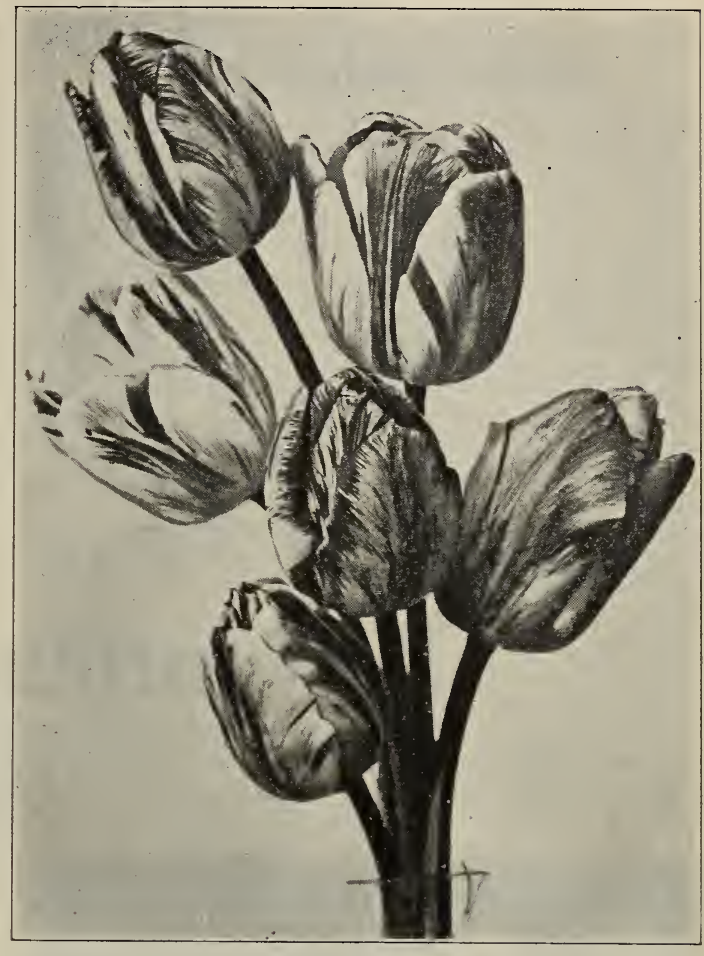

Bybloemen Tulips

Striped and Feathered

\section{SINGLE EARLY TULIPS}

For pots, beds and borders. They come in bright colors and bloom in March. Per doz. Per 100

Artus: bright red or scarlet, fine bold flowers. $\$ 35$

Belle Alliance: brilliant scarlet, yellow base... $\quad .55 \quad \mathbf{4 . 0 0}$

Chrysolora: pure golden yellow, the finest yel-

low for bedding........................ edge, fine and large.

Joost von Vondel: deep cherry red, feathered

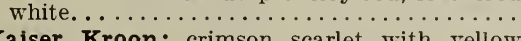

Kaiser Kroon: crimson scarlet with yellow margin................................ tint of pink, splendid for forcing and bedding

Pottebakker: Yellow-bright yellow, fine and large, very popular........................ Pottebakker: White-pure white, large showy

Pottebakker: scarlet-bright scarlet, fine for

prince of Austria : sweet scented, brilliant orange scarlet, long stems.......... silky and
Proserpine: glossy carmine rose, Proserpine:
effective.

Rosa Mundi: rose with white feather centering each petal. . . . . . . . . . . . . . . . . .

$.40 \quad 2.75$

3.25

4.50

2.00

\section{$.30 \quad 2.00$}

Rose Gris de Lin: white edged with rose, good

for forcing....................

Rose Tendre: rose and white.......... $\quad .50$

Van der Neer: $r i c h$ violet, large and fine..... $\quad .50$

White Hawk: the best pure white, large flowers,

long stiff stems:.

White Swan: large pure white, with egg-shaped flowers.

Yellow Prince: golden yellow, large and sweet scented...

Splendid Mixture of Single Tulips: good pro-

$\begin{array}{lll}.35 & 2.00 & \text { portions of various colors, } \mathbf{2 0 c} \text { per doz.; } \mathbf{\$ 1 . 2 5} \\ \text { per } 100 ; \mathbf{1 0 . 0 0} \text { per } 1000 \text {. }\end{array}$

$\begin{array}{lll}.35 & 2.00 & \text { portions of various colors, } \mathbf{2 0 c} \text { per doz.; } \mathbf{\$ 1 . 2 5} \\ \text { per } 100 ; \mathbf{1 0 . 0 0} \text { per } 1000 \text {. }\end{array}$

.352 .002 Morse's Special Mixture of named sorts is made up by ourselves of our best named tulips

2.50 and contains a great many varieties..........

Duc Van Thol: very early,

3.00 " " " "

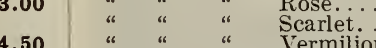

Vermilion...
White.......
.30

2.25

$\$ 2.25$

4.00

4.00

.00

2.00

\section{EARLY DOUBLE TULIPS}

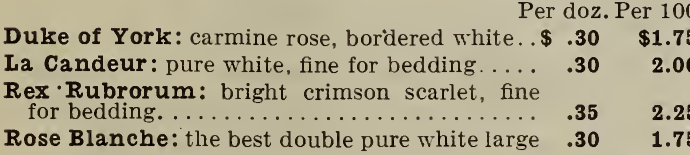

Tournesol: red-edged yellow, rery fine and

showy....

Tournesoi Yellow: bright yellow, shaded $\$ .40$

orange, brilliant. ........................... $\quad .50$

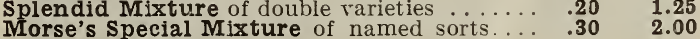

\section{PARROT OR DRAGON TULIPS}

These are for outdoor culture and especially desirable for borders or groups. The petals are curiously feathered on the edges, and the colors are frequently shaded with green a peculiarity of this variety. The blossoms are large and showy and very attractive.

Mixture of all colors. 


\section{Tulips-Continued}

\section{DARWIN TULIPS—SINGLE}

This variety has always long stems and finely formed cupshaped flowers. The colorings include rich shades of red, purple, and violet. as well as the lighter shades. They do well out of doors.

These are the Tulips which are illustrated on the back cover. Every garden needs some Tulips.

Asa Gray: deep carmine.

Clara Butt: a beautiful salmon pink, award of Merit, R. H. S. Donders: dark vermilion, violet center.

Europe: salmon scarlet.

General de Cordons: scarlet.

Giovanni: carmine rose, fine.

Glow: crimson scarlet, dark blue center, zoned white very fine.

Gustav Dore: bright pink.

Margaret: a lovely blush pink. Award of Merit; R. H. S.

Mrs. Krelage : rosy pink.

Mrs. Potter Palmer: purple

Olga: white and lilac.

Painted Lady: creamy white.

Pride of Harlem: salmon rose, shaded scarlet. Award.

Prima Donna: dark blue.

The Sultan: maroon black, showy.

Van Poortvliet: glowing deep red

\section{Polyanthus Narcissus}

DARWIN TULIPS-Continued

Per doz. Per 100

White Queen: white with only a suggestion of pink.

Wedding Veil: silvery lilac, black anthers.

Any of the above fine Darwin Tulips at .......\$ .90

2 Bulbs of each of above sorts (38 bulbs) for $\$ 2.50$

Named Darwin Tulips, our selection..................

Special collection of 10 fine sorts $\ldots \ldots \ldots \ldots \ldots \ldots . .60$

$\$ 6.50$

5.00

4.00

MIXED TULIPS-LATE

Bjzarre Tulips : a very striking and showy class of tulips. The ground is some shade of yellow - feathered, splashed or striped with crimson,

purple or white......
Bybloemen Tulips : brilliantly striped and splashed with blue, lilac, crimson, pink or scarlet on white ground. Long stems

Morse's Special Mixture of Late Single Tulips: made up by ourselves from named varieties; embraces all classes; nothing so fine elsewhere.

See inside of back cover for named varieties.
$30 \$ \$ 2.00$

2.00

(If wanted by mail add $12 \mathrm{c}$ per dozen for postage, and for Chinese lilies $3 \mathrm{c}$ each)

A very fragrant, sweet-scented type, of the easiest culture. Can be grown outdoors, in pots or in a dish of water with coarse gravel. The stems each bear from 10 to 20 blossoms at the top.

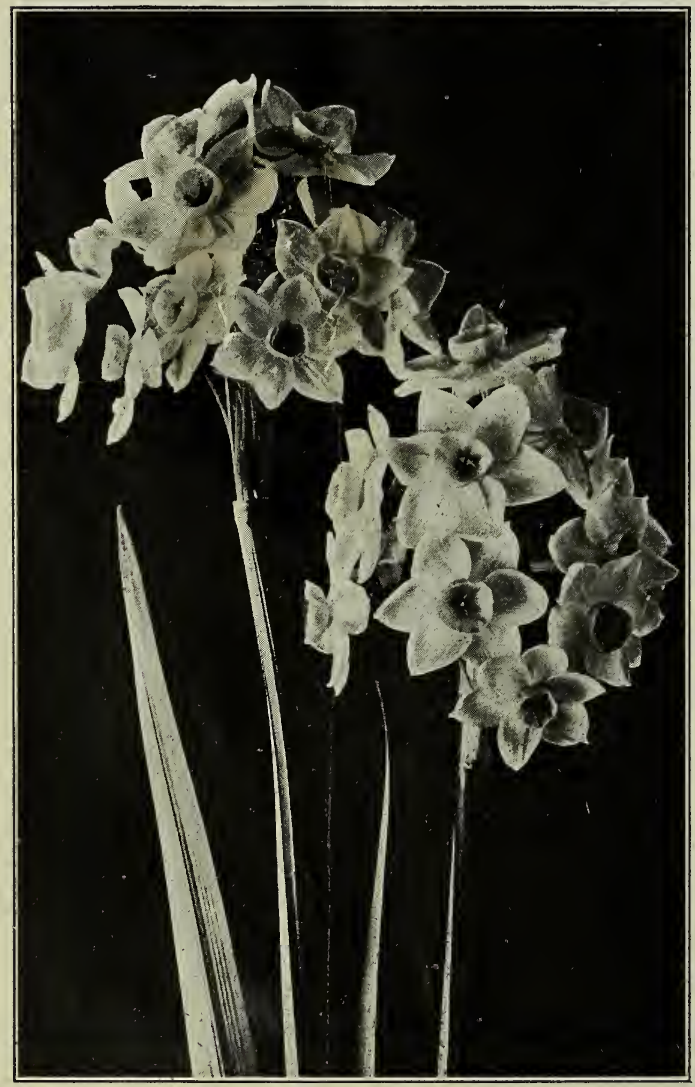

Polyanthus Type of Narcissus Paper White Grandiflora: blossom pure white. Grand Soleil D'Or: blossom deep yellow. Chinese Sacred Lily: blossom yellow and white
Paper White Grandiflora: beautiful Doz. $100 \quad 1000$ snowy white blossoms with large petals deliciously fragrant, the earliest to bloom. Will blossom out of doors by

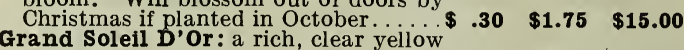
with orange cup. Very fragrant and Each Doz. 100 handsome................... $\$ .06 \quad \$ \quad \$ .45 \quad \$ 3.00$ Chinese Sacred Lily (single): perianth white, cup yellow, very free flowering and fragrant. Can be had in flower in dishes with water and coarse gravel dishes with water and coarse gravel
from December to March. We handle the finest selected bulbs imported from

China. 10c each;\$1.00 per doz; $\$ 2.25$ per basket of 30 bulbs. Extra size, 15c each; $\$ 1.50$ per doz.

\section{Poeticus Narcissus}

\section{(The Poet's Narcissus)}

(If wanted by mail add 5c per doz.; 25c per 100 for postage.) Poeticus (Pheasant's Eye): flowers large, snow white and the cup is margined with orange-red; blooms in May. Very fragrant. 2c each; 20c per doz.; $\$ 1.00$ per 100 .

Ornatus: an early flowering type and the best for forcing indoors. Fine large, symmetrical, snowy white flowers, with saffron cup, margined with scarlet. 3c each; 25c per doz.; $\$ 1.50$ per 100 .

\section{Jonquils}

These are much prized for their delicious fragrance, their graceful stems and blossoms, their rich golden hue and their fine hardy character. Half a dozen bulbs may be grown in a five-inch pot and forced, while they are easily grown also out of doors.

Postage 5c per dozen.

Per doz. Per 100

Single: very fragrant, rich golden yellow, cluster

of small flowers ......................... \$ .15 $\$ 1.00$

Double Jonquil: very sweet scented, heads small but very double and rich golden yellow.

Campernelle: large yellow flowers, fine for

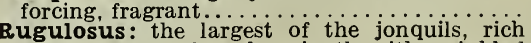
golden yellow, broad perianth with wrinkled

cup........................... .25 1.50

COLLECTIONS - Various Narcissus. A splendid mixture of the best Single Trumpet Daffodils. 40 c per doz.; $\$ 2.75$ per $100 ; \$ 25.00$ per 1000 .

A splendid mixture of the best Double Daffodils. 25 c per doz.; $\$ 1.75$ per $100 ; \$ 15.00$ per 1000 .

A splendid mixture of all Daffodils and Narcissus. 25 c per doz.; $\$ 1.50$ per $100 ; \$ 12.00$ per 1000 . 


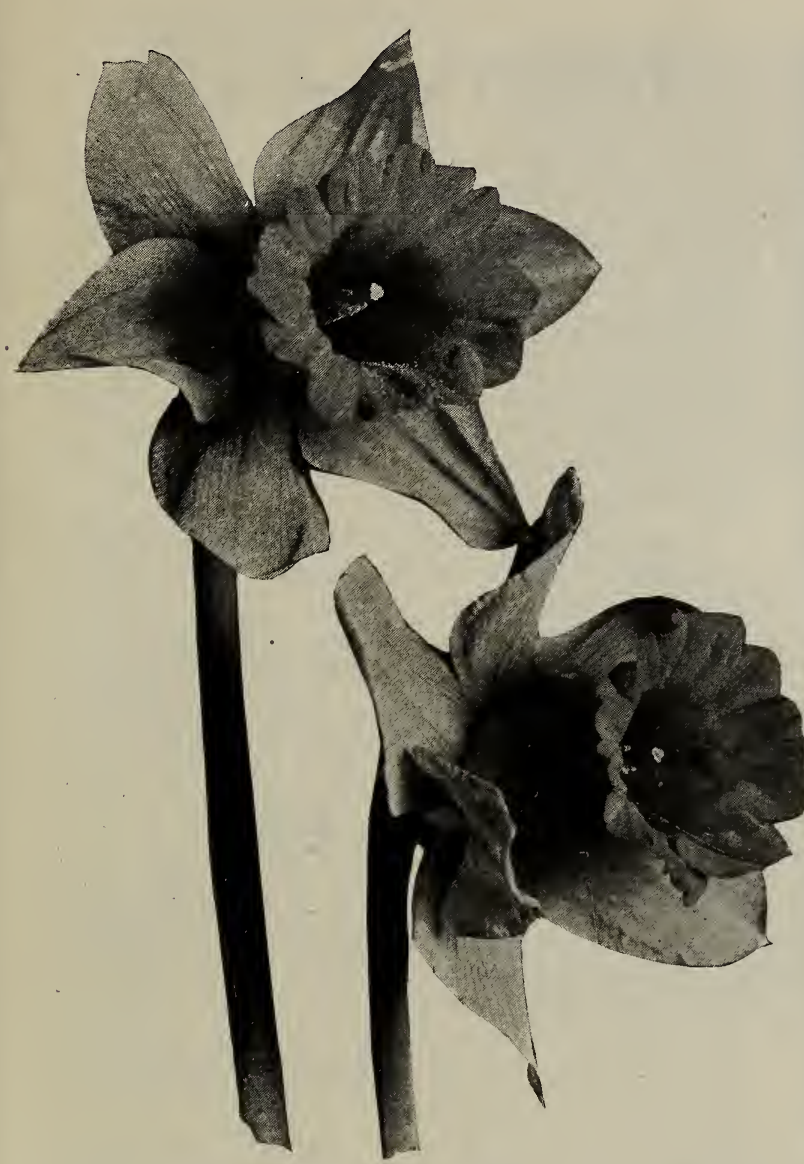

Emperor

The best Single Trumpet Daffodil

Madame De Graaf: a grand, new, clear white variety. The trumpet is slightly tinted cream, is also large and very delicate and graceful...............45c each; $\$ 4.50$ per doz.

\section{Daffodils}

There is no flower in the early spring that to our mind brings such refreshing inspiration as the Daffodil. They are such dainty, bright, clean flowers, and their fragrance so delightful that nothing else compares with them when they first come in their springtime glory.

They are the first to come after the dreariness of winter None of the Narcissus type is more delightful than the Daffodil (both single and double) and we have secured a splendid collection of them as offered below.

Plant Daffodils in October and November out in the open ground in good soil and let them remain from year to year. The bulbous roots will multiply and send up fine long flower stems every spring. Be sure to keep the ground moist during growing season if season is dry.

They can also be grown easily in pots, putting 4 or 5 bulbs into a 5-inch pot and keep well watered.

\section{LARGE TRUMIPET DAFFODILS}

If wanted by mail add 12c per dozen for postage.

B1-color Grandee: flowers very large with broad pure white petals which overlap each other. The trumpet is bright yellow. Rather dwarf and late flowering

4c each; 35c per doz.;\$2.50 per 100

Emperor: one of the grandest daffodils in cultivation; late. The perianth is broad and overlapping and the trumpet is very large and finely formed. Both perianth and trumpet a bright yellow. The stems are long and it is fine for cutting 7c each; 60c per doz.; $\$ 4.00$ per 100

Empress (White Wings): the perianth is pure white and the trumpet bright yellow. . .7c each; $60 \mathrm{c}$ per doz.; $\$ 4.00$ per 100

Golden Spur: a fine fragrant variety with long stems, excellent for cutting. The perianth is yellow and the trumpet is bright golden yellow; early

$\ldots \ldots \ldots \ldots \ldots$ 7c each; 60c per doz.; \$4.00 per 100

Henry Irving: one of the older varieties. The perianth has narrow petals of a deep yellow color, the trumpet is of a deep golden yellow and very large

6c each.50c per doz; $\$ 3.50$ per 100

obvallaris (Tenby Daffodil): a fine hardy flower, the perianth white, trumpet yellow

$\ldots \ldots \ldots \ldots . \ldots \ldots$ each; $50 \mathrm{c}$ per doz.; $\$ 4.00$ per 100

Princeps Maximus: very early and popular, perianth sulphur yellow, trumpet rich yellow.

$\ldots \ldots \ldots \ldots \ldots \ldots \ldots$. each; $30 \mathrm{c}$ per doz.; $\$ 2.25$ per 100

Single Von Sion: a beautiful golden yellow throughout (both perianth and trumpet), large and fine for cutting

$\ldots \ldots \ldots \ldots \ldots \ldots \ldots$ 6 each; 50 c per doz.; $\$ 3.50$ per 100

Trumpet Major: one of the most popular, large, clear yellow varieties (both perianth and trumpet same color). Valuable for bedding or cutting or for forcing. The most easily grown and the hardiest

$4 c$ each; $35 \mathrm{c}$ per doz.; $\$ 2.50$ per 100

Victoria: a new daffodil with broad white perianth and large yellow trumpet. The flower has great substance and keeping qualities. We recommend it as the best yellow and white and are glad to introduce it to this Coast.

7c each; 60c per doz.; $\$ 4.50$ per 100

\section{DOUBLE DAFFODILS}

These are all easily grown and are very pretty. (If wanted by mail add 10c per doz. for postage).

Alba Plena Odorata (the double White Poet's Narcissus or Gardenia Daffodil): sweet scented, very double and late. For outdoor culture only does not force well. 3c each; 25c per doz.; $\$ 1.50$ per 100 .

Incomparable (Butter and Eggs): rich yellow and orange, fine for either forcing or outdoors. 3c each; 30c per doz. $\$ 1.75$ per 100 .

Orange Phoenix (Eggs and Bacon): very large, double, white, and orange, very beautiful, fine for pot culture. 5c each $35 \mathrm{c}$ per doz.; $\$ 2.00$ per 100 .
Sulphur or silver Phoenix: creamy white with sulphur center, very double and beautiful. 6c each; 50c per doz.; $\$ 3.50$ per 100 .

Von Sion: the largest and finest double yellow trumpet variety. This is the old favorite variety so highly prized in old fashioned gardens. Excellent for either forcing or cut flowers. If planted out of doors it can remain where cut flowers. If planted out of doors it can remain where planted for a number of years, blossoming freely every year. dils should plant it. 5c each: $35 \mathrm{c}$ per doz.: $\$ 2.50$ per 100 .

\section{CROWN DAFFODILS (Chalice Cup or Star)}

Barril Conspicuus: broad, yellow perianth with a short, broad crown edged with orange-scarlet. 3c each; 25c per doz.; $\$ 1.75$ per 100

Cynosure: sulphur yellow perianth; yellow cup, stained with orange, scarlet; very showy, fine for cutting. 3c each; 25c per doz.; $\$ 1.25$ per 100 .

Sir Watkin: a giant flowering variety, the blossoms sometime measuring $51 / 2$ inches in diameter. The perianth is sulphur yellow; the cup deep golaen yellow. An old variety, still very popular. 5c each; 40c per doz.; \$2.75 per 100.

Stella: star-shaped, one of the first to bloom; flowers white with yellow cup; large and very free blooming. 3c each 25c per doz.: $\$ 1.25$ per 100.

Mrs. Langtry: pure white perianth, broad and overlapping; cup white edged, bright canary yellow, a fine art flower and very prolific. On account of its low price is largely used for naturalizing.' 3c each; 30c per doz.; \$1.75 per 100 . 


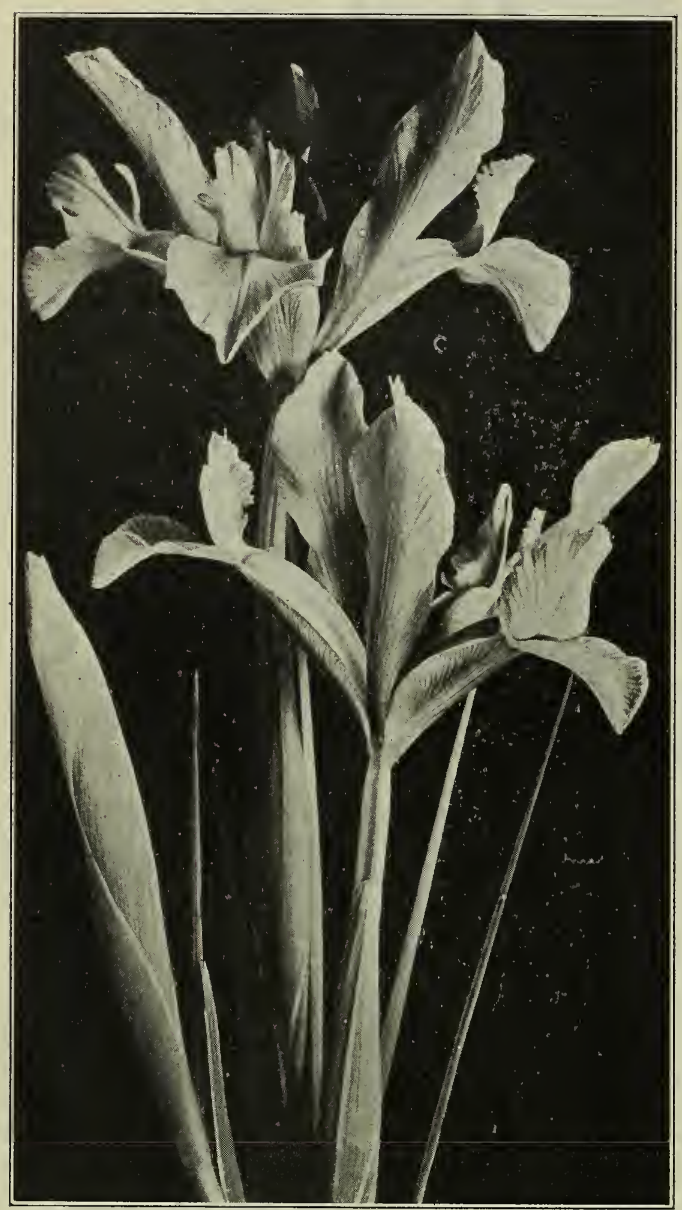

Spanish Iris

\section{Japanese Iris}

\section{(Iris Kaempferi)}

By universal consent, this species of Iris is given first place. It is one of the finest flowers we have, coming in various tint of blue, lavender, crimson, rose and lilac, as well as the dark blues and violets. The bulbs are perfectly hardy and the plants are very easily grown in any garden where there is good soil and plenty of water. The blossoms vary from 8 to 10 inches in diameter and are borne on long, graceful stems, blooming profusely in June and July. Bulbs are ready for delivery some time in December. We have some beautidelivery some time in December. We have som
fully colored pictures of these to show at our store.

In separate sorts-lavender, blue, white, claret, purple, etc. 25c each; $\$ 2.50$ per doz.

In mixed colors, 20c each; $\$ 2.00$ per doz.

(Bulbs too heavy to mail, postage 12s each.)

\section{English Iris}

These bloom several weeks after the Spanish Iris. The flowers are larger and are ver $y^{\circ}$ handsome, blue and purple shades predominating. Do not neglect watering these bulbs in the spring as they come to flower; you will be well repaid by the fine blooms.

Mixture, all varieties.

25c per doz.; $\$ 1.75$ per 100 Postage $5 \mathrm{c}$ per dozen

\section{Iris (Fleur-de-Lis)}

Iris, with its sturdy stems and orchid-like blossoms, comes in several different and very distinct types, each beautiful in itself. They come in a very wide range of tints and colors and are among the most delightful of all bulbous plants.

The bulbs should be planted 2 or 3 inches deep and 6 inches apart, and for best effect should be in beds or groups of twenty-five to one hundred or more bulbs; the greater the number the finer the effect.

A mulching of coarse manure or straw will facilitate the production of fine long stems and large blossoms.

After flowering, the bulbs may either be lifted or allowed to remain for another season. The varieties contained in our collection are the finest and most distinct in cultivation.

\section{Spanish Iris}

These are the most free-flowering and the earliest of all Iris, and should be in every garden. They are the cheapest in price, and can easily be afforded in large quantities for borders or brilliant bedding effects.

Alex von Humboldt: clear blue.

Belle Chinoise: very fine yellow.

Blanche Superbe: large white flower with a suggestion of pale porcelain shading; one of the best and earliest.

British Queen: purest white.

Cajanus: pure yellow; large flower, very tall, fine for cutting. Chrysolora :Tgolden yellow, the best of its color in cultivation. Darling :bright blue.

Gold Cup: darkest bronze, largest variety, very fine.

Formosa: the finest of dark blue.

Ida: deep yellow, large flower.

Louise: French gray and white, with golden blotch, very beautiful.

Philomena: fine large pale blue.

Snowball: pure white, shading to sapphire at base, with conspicuous golden blotch.

Splendens: deep blue.

Thunderbolt: dark bronze.

William I: fine yellow.

Postage 10c per 100.

Named Varieties, .......... all 15c per doz.; $\$ 1.00$ per 100 Mixed Blue Varieties. ........15c per doz.; $\$ 1.00$ per 100 Mixed White Varieties........15c per doz.; $\$ 1.00$ per 100 Mixed Yellow Varieties. ......15c per doz.; $\$ 1.00$ per 100 Splendid Mixture of all Varieties.

$2 \mathrm{doz}$. for $25 \mathrm{c} ; 100$ for $75 \mathrm{c} ; 500$ for $\$ 3.00$

From a letter received this spring. We like to know when our customers are pleased:

"During last November, we purchased about sixty bulbs from you. Every one is growing and all have bloomed except the Narcissus which are just coming up. We are greatly pleased."

Mrrs. J. F. Parlier, Parlier, Cal. 


\title{
German Iris
}

\author{
Postage $10 \mathrm{c}$ per dozen.
}

This variety is commonly called "Flags," and is a beautiful flower. as handsome as an orchid, and while the native blue and white are the most common, they can now be had in a great variety of colors and tints.

\section{All the following varieties.}

$85 \mathrm{c}$ per doz.; $\$ 6.00$ per 100

- Bulbs do not ripen until November.

Bouquet Royal: creamy white.

Canary Bird: standard yellow.

falls bronze, striped white.

Empress Victoria: pale blue standards, falls purplish blue.

Gloire de Hillegom: beautiful porcelain blue.

Grachus: crimson reticulated white, very fine.

Innocenza: ivory white.

Kharput: purple, standards blue. Madam chereau: white, elegantly frilled azure blue at the edges.

Maori King: rich golden rellow standards, falls velvety crimson margined gold.

Mrs. Horace Darwin: white slightly veined violet base.

spectabilis: deep velvety blue.

Mixtures of all the above varieties and many others not listed separately, $80 \mathrm{c}$ per doz.; $\$ 5.00$ per 100 Mixture, mostly blue shades

...45c per doz.; $\$ 3.00$ per 100 SUSIANA

\section{MOURNING IRIS}

(Prices are post-paid.)

This is a peculiarly beautiful variet $y$, and quite distinct from all other types, and must be seen to be appreciated. It is a combination of silvery gray and dark chocolate and black grows one foot high' and blooms in Ilay. The flowers are very large. being, 6 inches across. .....20c each; $\$ 2.00$ per doz.

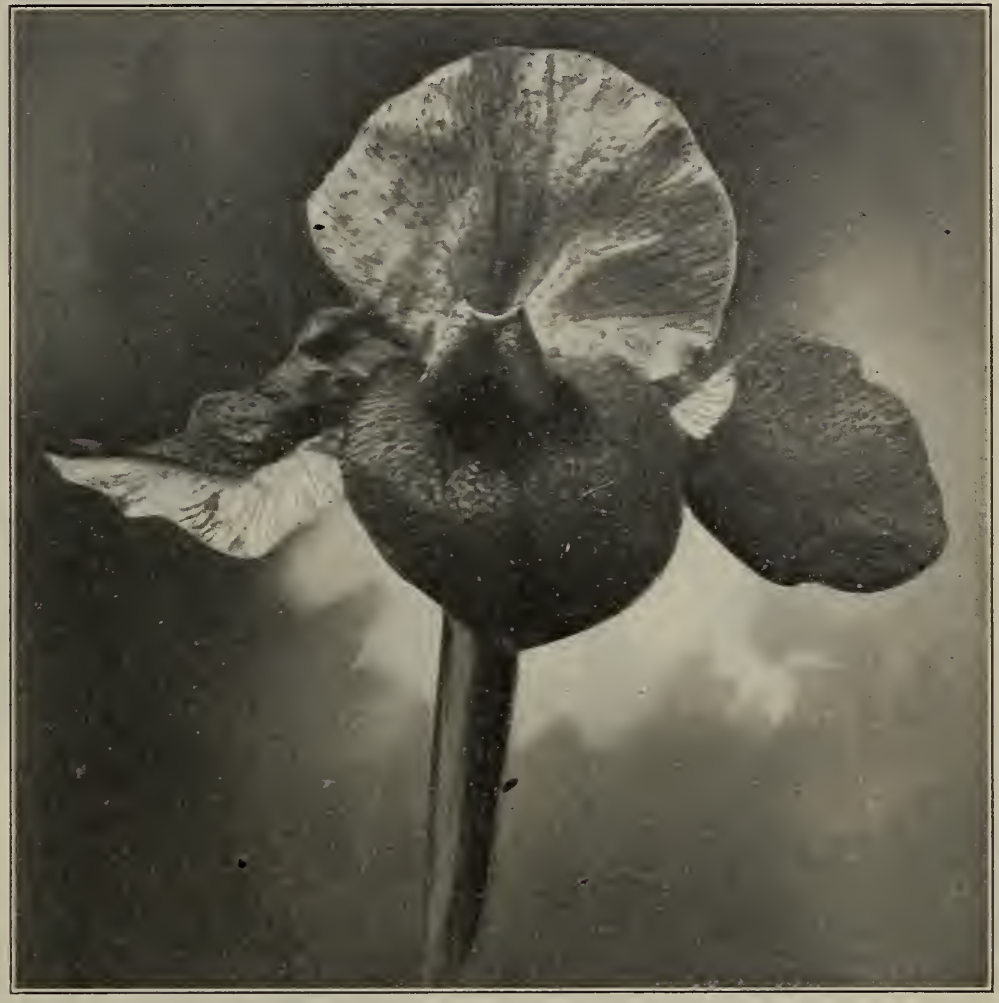

Susiana Mourning lris

\section{Lilies}

Lilies are matchless amongst hardy plants for beauty of form and variety of color in the garden. Ther commence form and variety of color in the garden. They commence
flowering in June, and with the rarious species. maintain a continuous and unbroken succession of bloom until autumn. Their stately habit, rich and varied colored flowers, often deliciously fragrant, and of easy culture, render them so distinct from all other hardy plants that no collection however select, should be without a few of the choicer sorts.

Candidum and Harrisii are ready for delivery in September, and the others in October and November.

If wanted by mail add $3 c$ each, 25c per doz., for postage.

CANDIDUM (Annunciation Lily; Madonna Lily; St. Joseph's Lily): The flowers are (pure snow-white and very
fragrant, borne on long stems. It is a valuable variety for forcing; and is the best white lily to plant out of doors, never failing to bloom well......15c each; $\$ 1.50$ per doz. (Postage $3 \mathrm{c}$ each; $25 \mathrm{c}$ per doz. additional).

Harrisii (The Bermuda Easter Lily): The flowers are trumpetshaped, pure white, gracefully formed and delightfully fragrant. This lily is the easiest to force into bloom, free flowering. ...............15c each; $\$ 1.50$ per doz.

Must be planted early. Order in september

Humboldt Magnificum: a remarkably fine variety attaining the height of 5 feet and bearing profusely large flowers of golden yellow, spotted with purple.

$.50 \mathrm{c}$ each

Leopard Lily: the native Tiger Lily found growing in the mountains in all parts of California; height 3 to 4 feet. Flowers jellow orange with dark spots.

Longiflorum Giganteum: a fine type of Japanese Easter lily, blooming about two weeks later than Multiflorum. ......15c each; $\$ 1.25$ per doz: and 25 c each; $\$ 2.00$ per doz.

Longiflorum Multiflorum: an early flowering type of the Japanese Easter lily. Pure white trumpet-shaped flowers.
Splendid for growing in pots and for outdoor planting. $15 \mathrm{c}$ each; $\$ 1.25$ per doz. ; extra large bulbs, 25 cach; $\$ 2.00$ per doz.

Philippine: A new, rare, hardy lily, grows two feet high and bears snow-white flowers with long trumpet; ten incheslong. Blooms in August. Bulbs ready in January.

Rubellum: of dwarf habit, bearing several beautiful rosepink flowers. Come into flower early. It does best. in sandy loam well drained.......20 each; $\$ \mathbf{2 . 0 0}$ per doz.

Speciosum Album: one of the most beautiful and easily grown lilies we have. The flowers are of immense size and pure white. Plants grow from 2 to 4 feet high

20c each; $\$ 2.00$ per doz.

Speciosum Rubrum: a beautiful variety, pure white, shaded rose and spotted with red; 3 to 4 feet high; a fine large flower.................15 c each; $\$ 1.50 \mathrm{per}_{\$} \mathrm{doz}$.

Speciosum Rubrum Magnificum: this variety is much more crimson in color than the ordinary Rubrum and is $15 \mathrm{c}$ each; $\$ 1.50$ per doz.

Tigrinum (Tiger lily) : fine showy blossoms, brilliant orangered spotted with black; 3 to 5 feet high, and blooms in August...................... 15 c each; $\$ 1.25$ per doz.

Tigrinum Flora Plena (Double Tiger Lily): Similar to Tigrinum, but bearing flowers that are double

$15 \mathrm{c}$ each; $\$ 1.50$ per doz.

Washington Lily: a grand variety from Oregon and Washington; flowers are large and fragrant: opens white and turns to purple and lilac. They bloom freels in the summer 3 to 5 feet high.............50 each; $\$ 5.00$ per doz. 


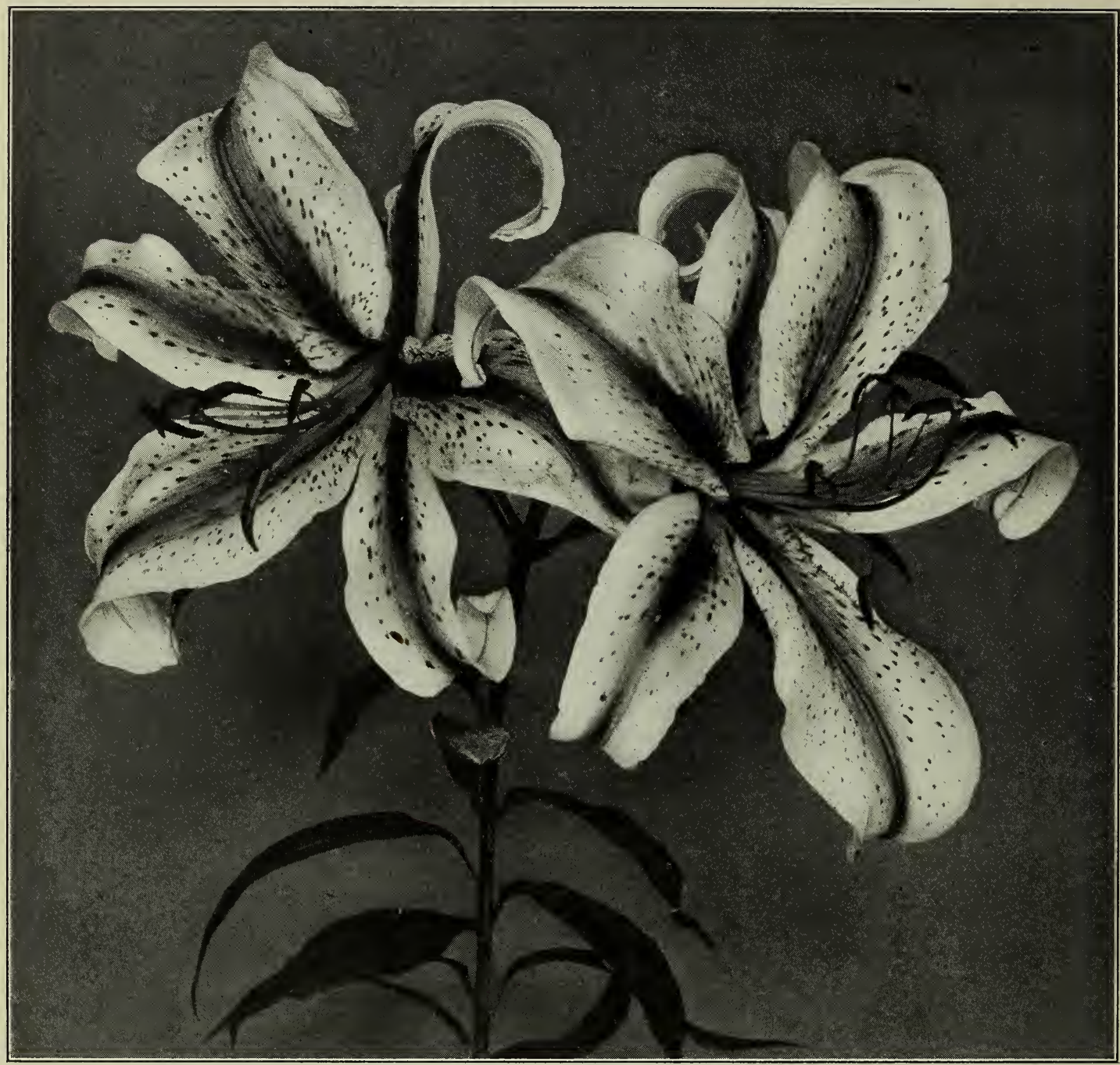

Lily Auratum Rubro Vittatum

These were raised out of doors and were 10 inches each across. All Auratum Lilies are of same size and habit but with different coloring in the center of the petals

\section{Lilies--Continued}

Auratum (Gold-banded Lily): one of the finest and most popular of the hardy garden lilies. The blossoms are composed of six large petals of delicate ivory white, studded with spots with a bright golden band running through the center of each petal. The flowers when fully expanded are nearly a foot in diameter, are very fragrant and bloom from June to October. $\mathbf{1 5 c}$ and $25 \mathrm{c}$ each, and $\$ \mathbf{1 . 5 0}$ and $\$ \mathbf{2 . 5 0}$ per dozen, according to size.

Auratum Pictum: similar in form to the Auratum, but tipped with crimson at the ends of the' yellow rays, 35c each; $\$ 3.50$ per doz.

Auratum Platyphyllum: similar to Auratum, but larger and finer in all respects. Especially noted for its broad lustrous leaves which give double attraction. The petals are studded with crimson chocolate spots. $\mathbf{3 5 c}$ each; $\mathbf{\$ 3 . 5 0}$ per doz.

Auratum Rubro Vittatum: one of the finest of all lilies Its crimson band running through the middle of the petal is so broad that the petals appear to be crimson margined is so broad that the petals appear to be crimson margined Belladonna Lily: see Amaryllis Belladonna
Elegans Atrosanguinea: a dark blood-red lily of handsome appearance. Elegans lilies are all borne erect on a stem about $21 / 2$ feet tall.............20 each; $\$ 2.00$ per doz.

Elegans, Incomparable: the richest red known in lilies, a deep crimson slightly spotted with black. Flowers large and freely borne.............20 each; $\$ 1.75$ per doz.

Elegans, Orange: a very early flowering lily, doing well in any location, about 2 feet high, flowers are orange in color $\ldots \ldots \ldots \ldots \ldots \ldots \ldots \ldots \ldots . \ldots \ldots$ 20 each; $\$ 1.75$ per doz.

Henryi (The Yellow Speciosum): a rare lily from China, hardy and free flowering. Flowers are a rich apricot yellow slightly spotted with brown ............. 75c each

Krameri: a beautiful large pink lily, distinct from all others. The flowers shade lighter and are very fragrant

$\ldots \ldots \ldots \ldots \ldots \ldots \ldots \ldots \ldots \ldots \ldots \ldots$ 20c each; $\$ 2.00$ per doz.

White Calla Lily (Calla Ethiopica): the well known and popular white Calla. According to size.

Yellow Calla Lily (Calla Elliottiana): is the only true yellowflowered calla in existence. The foliage is dark green with a number of translucent white spots, and the flowers a bright yellow. A very handsome sort. According to size, 25c to $35 \mathrm{c}$ each; $\$ 2.50$ to $\$ 3.50$ per doz. 


\section{Miscellaneous Bulbs and Flowering Roots}

\section{AGAPANTHUS, UMBELLATUS (The Blue African Lily) \\ (Too heavy to mail)}

The old favorite, flowers bright blue borne in clusters of 20 to 30 . The flower stalks frequently attain a height of three feet, the flowers opening in succession for a long period during the summer and autumn. Ready for November delivery..

25c each; $\$ 2.50$ per doz. Agapanthus Albus: a new white variety, very beautiful. A

\section{ALLIUM, AUREUM}

(Postage 5c per doz.)

Molly or Golden Allium: one of our most showy border plants; perfectly hardy, bearing large umbels of golden yellow flowers in June. A very old favorite, and fine for naturalizing in the garden where it forms large clumps. Height, one foot. . . . . . . . 15c per doz.; $\$ 1.00$ per 100

\section{AMARYLLIS}

(Postage 15c per bulb)

Ornamental plants with large, fragrant, beautifully colored flowers. Frequent disturbance of the roots should be avoided as this will prevent free flowering. Sends up a flower stalk without leaves in August to a height of $21 / 2$ feet, very fragrant. Belladonna Major, beautiful soft rose.

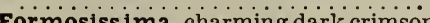

\section{ANEMONE (Poppy-flowered)}

(Prices are postpaid)

Popular hardy perennials, 12 inches high, bearing in spring bright flowers of scarlet, white, rose, blue and lavender. Useful for beds and borders. The Japanese Anemone, or Wildflower, is a wholly different plant and is offered in our large spring catalogue.

Scarlet: rich, dazzling scarlet....30c per doz;\$2.00 per 100 Scarlet: fl.pl. double form of above.40c per doz; $\$ 3.00$ per 100 Double: all colors mixed....... 30 per doz; $\$ 2.00$ per 100 Single: all colors mixed.......25c per doz; $\$ 1.50$ per 100

\section{BEGONIA (Tuberous-Rooted)}

(Prices include postage)

For January delivery. Splendid pot plants, and equally useful for bedding purposes; very free flowering, doing best with partial shade.

We offer Begonias in the following separate colors: dark rose, light pink, salmon, scarlet, white and yellow.

Double: all colors separate or mixed . .15c each; $\$ 1.50$ per doz. Single: all colors separate or mixed...10c each; $\$ 1.00$ per doz. Begonia Crispa: a new sort with very large single flowers beautifully frilled on edge and crested. Try some of these new ones. . . . . . . . . . . . . 25c each; $\$ 2.50$ per doz.

\section{BRODIAEA}

Prices include postage)

Laxa (Ithuriel's Spear): bears a cluster of twenty or more of clear blue flowerets on a stem 1 to 2 feet high. One of the beautiful wildflowers of California in May and June

....................20c per doz.;\$1.25 per 100

\section{CALOCHORTUS OR MARIPOSA TULIPS}

(Also called Mariposa Lilies)

(Price includes postage)

These famous California wild flowers possess much delicacy and brilliancy of coloring. They somewhat resemble a tulip in shape, are of many colors, shades and markings. Planted in the open border, they flower in June and July. Mixed Calochortus. .................30c per doz.; \$2.00 per 100

\section{CROCUS}

(Postage 15c per hundred)

Should be planted liberally in lawns and grass plots, where they will flower very early in the spring, before mowing.

Mixed blue and purple. ........10 c per doz.; 60c per 100

Mixed whites . . . . . . . . . 10 per doz.; 60c per 100

Mixed striped varieties.........10c per doz.; 60c per 100

Yellow, large size ...........15c per doz.; $\$ 1.00$ per 100 King of the Blues: extra large flower

Queen of the Whites: extra large flowers

15 c per doz.; $\$ 1.00$ per 100

Splendid mixed, a finely proportioned mixture of all the best varieties...................10c per doz.; 50c per 100

\section{CROWN IMPERIALS (Fritillaria Imperialis)}

\author{
(Postage 3c each)
}

Well known spring blooming, stately, hardy border plants with clusters of immense pendant, bell-shaped flowers, surmounted with a tuft of green leaves. They are very effective, and if left undisturbed for years they form gigantic and picturesque groups, bearing gorgeously colored flowers. picturesque groups, bearing gorgeously colored flowers.

\section{CYCLAMEN, GIANT FLOWERED}

(For December Delivery)

(Prices are postpaid)

A beautiful winter greenhouse or pot plant, with beautiful deep green leaves, and long graceful stems bearing curiously winged blossoms in white and crimson shades. While these may be grown from seed, the best flowers are produced from bulbs.

Persicum Giganteum, giant flowered Rose.....\$ .20 \$2.00 Persicum Giganteum, giant flowered White.... $\quad .20 \quad 2.00$ Persicum Giganteum, giant flowered Crimson .. $\quad .20 \quad 2.00$ Persicum Giganteum, giant flowered, mixed colors.

\section{DIELYTRA OR "BLEEDING HEART"}

Postage $5 \mathrm{c}$ each)

One of the most ornamental of spring-flowering plants, with long, drooping racemes of heart-shaped flowers. If potted in December, left outside till it has formed new roots and then brought in to a gentle heat, it may be had in flower in the greenhouse in February and March.

Spectabilis: magnificent racemes of pink and white flowers. . ...................25c each; $\$ 2.50$ per doz

\section{GLADIOLUS}

(For September and November delivery. Prices are postpaid)

Early Flowering Sorts: these are more slender and somewhat smaller sorts. They bloom early and are largely used for cut flowers, especially on Decoration Day. (for other varieties of Gladiolus see our annual catalogue issued in December.) Colvilli, “The Bride:" ready in September. Pure white, very handsome and good to force.

25c per doz.; $\$ 1.50$ per 100

Colvilli "Rosea:" like the above, colored pink

25c per doz.; $\$ 1.75$ per 100

Cardinalis, Mixed: this has many pink and red shades with a blotch at the base of each petal.

25c per doz.; $\$ 1.50$ per 100

\section{FREESIAS}

(For September and October delivery. Prices are postpaid.)

Greatly prized for the delightful fragrance of the delicatel colored flowers, which, when cut, remain in good condition for a long time in water. Flowers are borne on stems from 9 inches to 2 feet high in early winter if planted in September. The larger bulbs bear more flowers.

Per doz. Per 100

Refracta Alba: pure white, delightfully fragrant.\$ .15 \$1.25

Extra large bulbs.................. .25 $\quad \mathbf{1 . 7 5}$

Leichtlinii: large fragrant, pure yellow....... $\quad .30 \quad 2.00$

Purity: an improved type with pure white flowers of immense size.

Scarlet: a dazzling rosy carmine color, with a

dark crimson spot on three lower petals....

\section{GLOXINIAS}

(For December delivery. Prices are postpaid)

Most charming greenhouse plants, of dwarf habit. Their flowers, often 3 to 4 inches across, are produced in greatest profusion, and are of the most exquisite and gorgeous colors. many of which are magnificently spotted, mottled, and blended. They bloom continuously for months, and by starting at intervals, a succession of their splendid flowers may be had nearly the whole year round $15 \mathrm{c}$ each; $\$ 1.50$ per doz

\section{HYACINTHUS CANDICANS}

(Postage $3 \mathrm{c}$ per bulb)

Free growing, summer-flowering plants with flower stems 2 to 4 feet high, each bearing from 20 to 30 large white bellshaped flowers; splendid for groups....7c each; $75 \mathrm{c}$ per doz. 


\section{Miscellaneous Bulbs and Flowering Roots-Continued}

\section{IXIAS}

(Prices are postpaid)

The Ixia is a beautiful little winter-flowering bulb, with low slender, graceful spikes of bloom. The colors are rich, varied, and beautiful.

Per doz. Per 100 Crateroides Major: brilliant scarlet, good for forcing. Viridiflora: bright soft green with velvety black center

$.40 \$ 3.00$

Wonder (Rosea plena): deep pink flowers, double and very fragrant....... splendid Mixture of all varieties containing a $.50 \quad 4.00$ $35 \quad 2.50$ great many varieties and colors...........
LILY-OF-THE-VALLEY

(For December and January delivery)

For pot culture or forcing by those who have conservatories these cannot be excelled, producing large, fragrant spikes, crowded with bells, and an abundance of dark green foliage. Selected pips for out of door planting in bundles of 25 , 60c (70c postpaid); per 100, \$2.25.

Selected pips for forcing, bundles of $25,60 \mathrm{c}$ (70c postpaid): per $100, \$ 2.25$; per $1,000, \$ 20.00$.

Clumps for outdoor planting, 60c each. Add 10c for postage.

\section{MONTBRETIA}

(Prices are postpaid)

A summer flowering bulb, bearing bright colored flower on long, graceful spikes, foilage is long and graceful, and resembles that of the gladiolus. Valuable for cutting, and makes a beautiful display in a clump on the lawn or for borders. Blooms July to September.

Per doz. Per 100 Crocosmiaeflora: fine scarlet and yellow .......\$ $\mathbf{. 2 0} \quad \underset{\mathbf{\$ 1 . 2 5}}{\mathbf{1 0}}$ Crocosmiaeflora: Etoile de Feu (Star of Fire).

bright vermilion, center yellow, outside blood

red............................

$.25 \quad 1.50$

(Postage 10c per doz.)

Arabicum: a beautiful variety, throwing up a tall spike bearing numerous large, milk-white, star-shaped flowers, with a black center, and having a distinct aromatic perfume. They are of the easiest culture.5c each; 50c per doz.; $\$ 4.00$ per 100 .

\section{OXALIS}

(Prices are postpaid)

Charming little half-trailing or bushy plants, adapted for pot culture, hanging baskets and borders. The foliage alone pot culture, hanging baskets and borders. The foliage a
is very attractive. They flower all spring and summer.

Bermuda Buttercup, pure bright yellow...\$.25 $\underset{\$ \$ 1.50}{\text { Per doz. }}$ Boweil, bright rosy crimson $\ldots \ldots \ldots \ldots \ldots \ldots . .25$

\section{OXALIS-GRAND DUCHESS}

The Grand Duchess type is a California variety of dwarf, sturdy growth, with fine large flowers, very free flowering.

Grand Duchess: white.

Grand Duchess: pink.

Grand Duchess: lavender.

Grand Duchess: mixe

\section{RANUNCULUS}

(Prices are postpaid)

Per doz. Per 100

$\$ .25 \$ 1.50$

$\begin{array}{lr}.25 & 1.50 \\ .25 & 1.50\end{array}$

$.20 \quad 1.25$

$.15 \quad 1.00$

French Mixed: fine large, loosely double flow-

Persian Mixed: very double rose-shaped

flowers.

Turban ivixed: double paeony-shaped flowers

in many bright color

\section{SCILLA OR WOOD HYACINTH}

(Postage 4e per doz.)

Charming little plants that do well under trees or in other shady situations, rendering such spots bright and cheerful. Siberica: exquisite blue, adapted for edging

\section{SNOWDROPS}

20c per doz.; $\$ 1.25$ per 100

(Prices are postpaid)

Nothing is more beautiful than these little modest flowers, appearing in earliest spring. If dotted throughout the lawn, the effect is most charming.

California Giants: a vigorous growing, large-

Double Flowerin

$.20 \$ 1.00$

$.15 \quad .90$

\section{SPARAXIS}

(Price is postpaid)

Beautiful flowers borne on long, graceful spikes; the colors are of the most telling combinations and of the brightest shades. They are tigered, blotched, spotted, streaked and flushed in the most diverse and pleasing manner. The bulbs flower during the winter and spring.

Mixed colors. . .............20 per doz.; $\$ 1.00$ per 100

\section{SPIREA}

(Postage 10c each bulb)

(For December Delivery)

While these can be used for outdoor planting where they will bloom during the summer, their great value lies in their ease of culture as a house plant.

Ja ponica Compacta Multiflora: dwarf, and a dense flowerer ciumps; too heavy to mail.......25c each; $\$ 2.50$ per doz Gladistone (Hybrid Astilboides): the best of all the Spireas,

bearing snow-white plumes in great profusion

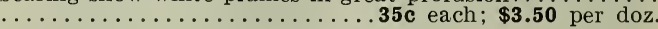

\section{TRITELEIA}

(Price is postpaid)

A very pretty flower for border or bed, 6 to 8 inches high, star-shaped, color white suffused with blue, hardy

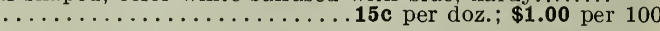
TUBEROSES

(Postage 12c per doz.)

(For January delivery)

The flowers grow on stems 18 inches high, each stem bearing a dozen or more flowers. They are pure white, waxlike, double and very fragrant.

Double Dwarf Pearl. . ........40c per doz.: $\$ 3.00$ per 100

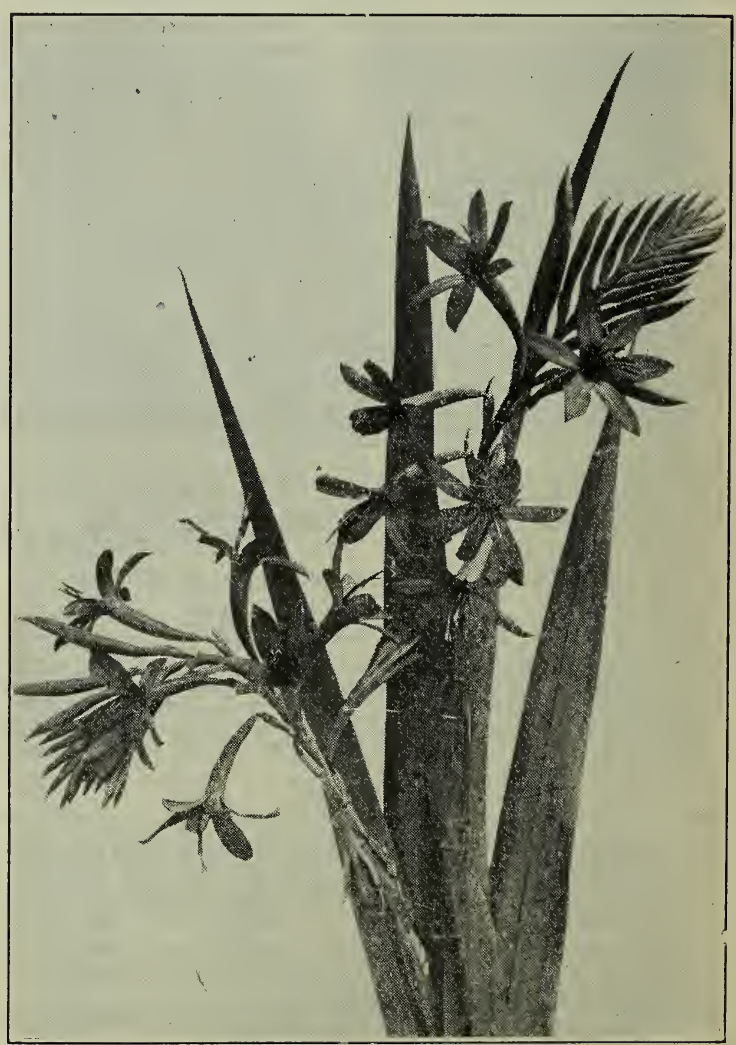

Montbretia-Scarlet and Yellow

In glorious bloom in August 


\section{C. Morse \& Co. FLOWER SEED San Francisco, CaL.}

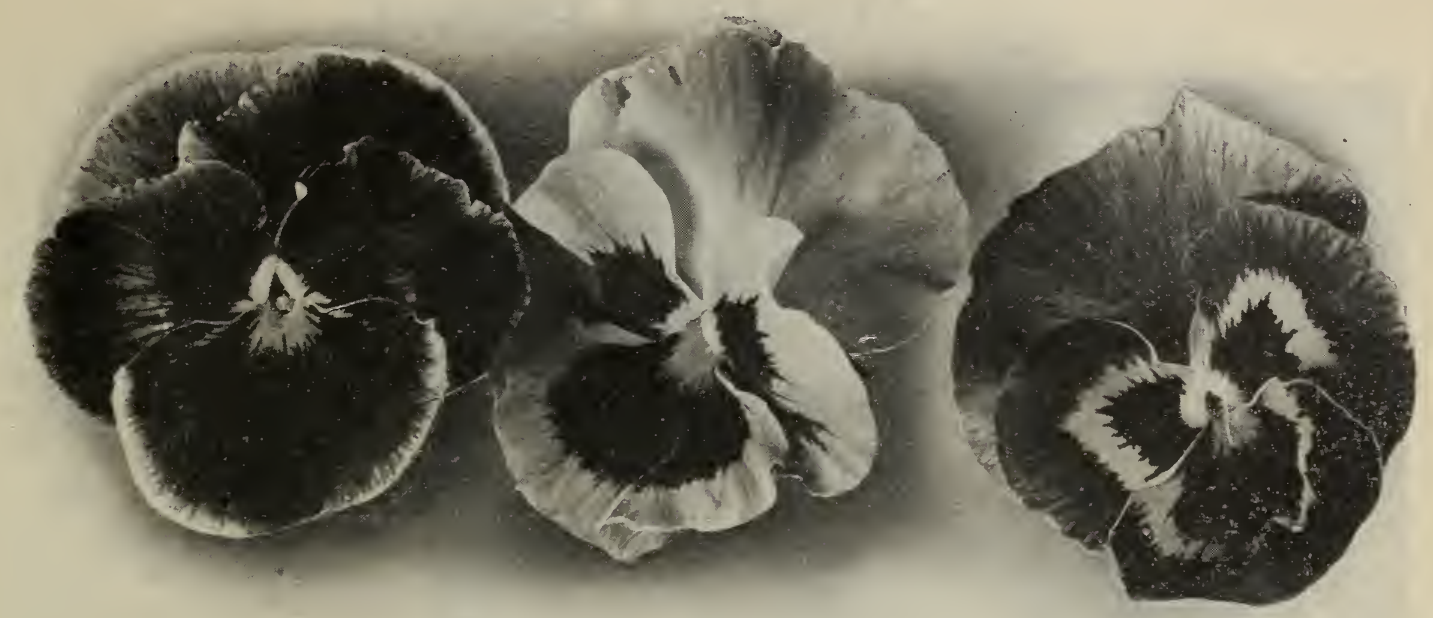

Morse's Prize Strain Pansies

About $2 / 3$ natural sizé

\section{Morse's Superb Pansies}

All our Pansy seed is obtained from the most noted European specialists. Pansies thrive best in a moist, shady location and in rich, loamy soil. Seed should be sown in the autumn for early spring blossoms, or can be sown early in the year for good flowers later in the spring. The blossoms are usually larger in the spring and again in the fall, and while they bloom freely all summer, the blossoms are small during the hot months. While the plants carry over well with a little coveling during the winter, it is best to plant new seed each year.

We offer the following extra selected strains of superior large flowers especially for pansy fanciers, all at 25c per pkt. Special offer, 5 pkts. $\$ 1.00$ :

Dr. Faust, jet black; Five Spotted on white ground; Striped Mixed; Azure Blue, white edge; Giant Fancy, light blue; Goldelse, clear yellow; Cardinal, blood red; Emperor William, purple, violet shaded; Snow White.

\section{SPLENDID MIXTURFS}

MORSE'S PRIZE STRAIN. The Seed of Morse's Prize Strain Pansy is grown for us by a noted specialist in Germany, and is saved from exhibition flowers, including almost every shade of color, exquisitely spotted and blotched, veined, mottled and margined, and fancy varieties. This strain is so beautiful that no description or praise can do it justice, being unsurpassed for rich and varied colors and immense size. Pkt. of 500 seeds, 50c.

Morse's Imperial German Strains Mixed: a superfine mixture of the choicest German varieties in all colors. Pkt., 25c.

Bugnot Mixed: a circular, ruffled, and five-petaled type, with soft, blended colors and tints, veined on the margins and with a dark blotch at the base of each petal. One of the finest varieties. Pkt., 25c.

Cassier's Giant, Mixed: a splendid mixture of various shades and markings. The blossoms are perfectly round and are blotched at the base of 3 to 5 of the petals. Pht., 25c.

Giant Trimardeau, Mixed: the largest-flowering type of pansies, called the French strain. The top petals are larger than the three lower ones and are beautifully marked. Pkt., 15c; Oz., $\$ 2.00$.

Giant Odier or Prize Blotched, Mixed: a large flowered type, with round blossoms. The petals are all blotched at the base and distinctly margined on the edge. Pht., 25c.

Giant Masterplece: these new pansies have a most beautiful combination of rich velvety coloring and attractive wavy or ruffled petals. This wavy effect gives a graceful appearance rarely seen in pansies, and while they are really very large, they appear larger on this account. Pkt., 25c.

\section{THE BEST SEPARATE COLORS OR NAMED VARIETIES}

Atropurpurea: dark blue.

Pkt. Oz.

Auriculaeflora: fine shades.

$\$ .10 \$ 2.00$

Azure Blufe: $\ldots . .10 \quad 2.00$

Bronze........................... $10 \quad 2.25$

Emperor William: Ultramarine blue........ $\quad .10 \quad 2.00$

Fairy Queen: blue with azure margin. . . . . . . . $10 \quad 2.00$

Fire King: crimson, Jellow edge. $\ldots . .25$

Golden Gem: pure yellow. . . . . . . . . . . . .10 2.00

Gold Margined......... $10 \quad 2.00$

Golden Yellow: dark ere............... $.10 \quad 2.00$

King of the Blacks or Faust: velvety black . $\quad .10 \quad 2.25$

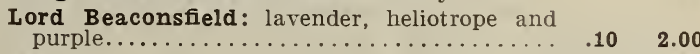

Peacock: peacock blue, white edge.......... $\quad .10 \quad 2.50$

Prince Bismarck: golden bronze. . . . . . . . . . $10 \quad 2.00$

Quadricolor: or Pheasant's Ere. . $\quad .10 \quad 2.00$

Ruby Red: rich color..................... .10 2.75

Silver Edged: extra fine. $\ldots . . .25$

Snow Queen: pure white.................. $\quad .10 \quad 2.25$

Victoria: nearly scarlet $\ldots \ldots .10 \quad 2.25$

Violet: fine violet, blue ................. $\quad .10 \quad 2.00$

White: pure white, dark eye............... $10 \quad 2.00$

Large Flowering Varieties: all Mixed. Pkt., 10c; oz., \$1.50. Striped or Mottled, Mixed: Pkt., 10c.

12 packets of any of the above $10 \mathrm{c}$ varieties for $\$ 1.00 ; 6$ for $50 \mathrm{c}$ 


\section{Sweet Peas}

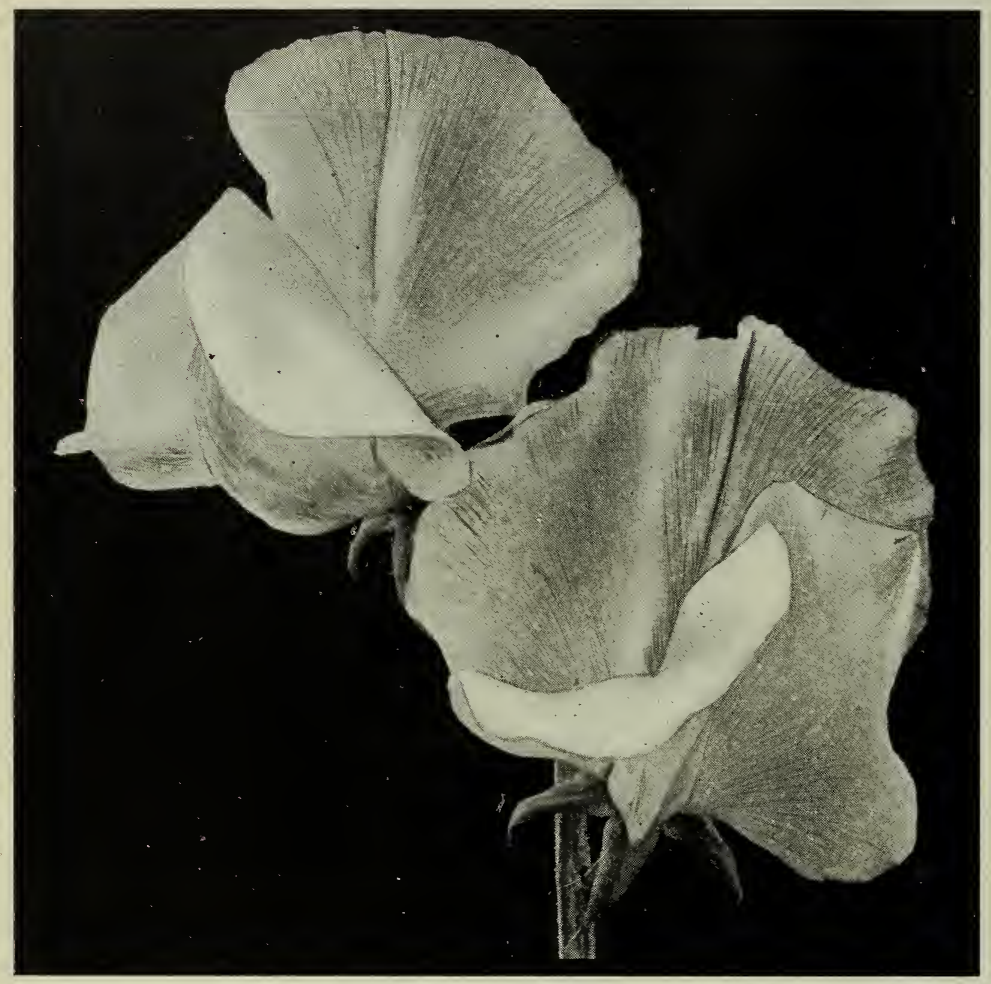

Miriam Beaver

This illustration represents all of the "Spencer Type" of Sweet Peas. Wavy petals, large wings and very large flowers, 2 inches across, but four flowers are borne on a stem.

\section{WHITE}

White Spencer: our selection and true

large, wavy, pure white.

Emily Henderson: hardy, free bloomer. $\quad .10$

Mont Blanc: early forcing variety ..... $\quad .10$

Shasta: large fluted white......... .10

White Wonder: large double white... $.10 \quad .25$

Mrs. Sankey spencer: black seedlarge white. . .............. 15c .35 1.00

\section{PALE YELLOW OR PRIMROSE}

Primrose Spencer: large wavy Spencer $\begin{array}{llll}\text { type, light primrose. . ...... } 1 \text { kt. 10c } & .25 & .75\end{array}$

Hon. Mrs. E. Kenyon: a fine large clear

$\begin{array}{rrr}\text { primrose........................... } & .10 & .20 \\ \text { Queen Victoria: black seed-primrose... } & .10 & .20\end{array}$

Queen Victoria Spencer: very large, VERY LIGHT PRIMROSE AND PINK

Golden Rose: primrose striped blush ... $\quad .10 \quad .20$ and light pink, hooded and large....... pink.

$\begin{array}{rr}.10 & .20 \\ .10 & .20 \\ .10 & .20\end{array}$

W. T. Hutchins (Spencer): buff and blush. ................2kt.25c

\section{DEEPER PINK SHADES}

with wavy edges...................... clear pink at the base and

shading to buff at the edges...........

Beatrice spencer: large buff pink and rose.
Dorothy Eckford: large shell shaped .

\section{.................... Pkt. 15c .35 1.00}

Marchioness of Cholmondeley: buff

Countess Spencer: giant flowered pink
The months of NOVEMBER and DECEMBER ARE THE BEST TIME TO SOW SWEET PEA SEED. It is best to order your Sweet Pea Seed early and sow it when the first rains come. Then you get blossoms in May and June, when they are large and splendid. They do very well, however, sown any time duing the winter or spring.

We have the following four GRAND NEW SPENCER TYPES ready for introduction this year: Miriam Beaver: beautiful apricot pink.

W. T. Hutchins: buff and blush pink.

Senator Spencer: $\mathrm{ch} \mathrm{ocol}$ a t e striped on white.

Prince of Wales Spencer: bright carmine rose.

Each will be offered at 25c per packet. The seed supply of these is very short.

\section{IIGHT PINK SHADES}

$1 \mathrm{lb}$. $\$ 2.50$ .60 .50 .50 .60 .60

3.50 2.50

.50 .50

3.50 .50 .50 .50

$(50$

col

Ramona Spencer: white, striped blush 1 oz. $1 / 4 \mathrm{lb} .1 \mathrm{lb}$. Florence Morse Spencer: giant white
and blush with pink edge.... Pkt. 10 Gladys Unwin: large wavy, delicate Gladys Unwin: large wavy, delicate
pink, a little deeper at the edges...... Katherine Tracy: soft pink standards with lighter pink wings..............
Prima Donna: a clear, soft pink self color with shell-shaped standard........... $\begin{array}{llll}\text { Venus: buff pink, deeper at full maturity } & .10 & \mathbf{. 2 0} & \mathbf{. 5 0} \\ \text { Mrs. Routzahn spencer: buff and prim- } & & & \end{array}$

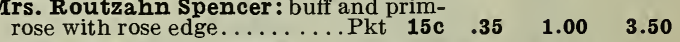

Apple Blossom: crimson-pink; wings

white, tinted with pink .............

Earliest of All: or extra early Blanche Ferry. Bright rose standard with white wings ..................... 10

$\begin{array}{llll}\text { ROSE AN } & \\ \text { Jeannie Gordon: rose and primrose.... } & .10 & .20 & \mathbf{. 5 0} \\ \text { Royal Rose: crimson and pink........... } & \mathbf{. 1 0} & \mathbf{. 2 0} & \mathbf{. 5 0}\end{array}$

Apple Blossom spencer: rose and primrose, tinted pink. ........... Pkt., 15c BLUE AND PURPLE SHADES

Countess of Cadogan: (Improved Capt. of the Blues), purple standard with

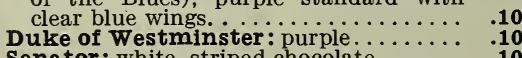
Senator: white, striped chocolate......... .10 Capt. of the Blues Spencer : giant wavy purple. . ............... Pkt. 15c Senator spencer: chocolate and white $\begin{array}{lll}.10 \quad .20 & .50\end{array}$ .10

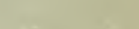
$\begin{array}{lll}.25 & .75 & 2.00\end{array}$ $.10 \quad .25 \quad .60$ striped. . ................ Pkt. 25c $\begin{array}{rrr}.10 & .20 & .50 \\ .10 & .20 & .50 \\ .10 & .20 & .50 \\ .35 & 1.00 & 3.50\end{array}$ Price per packet is $5 c$ except where noted otherwise. All prices include postage 


\section{Sweet Peas-continued}

Price per package is $5 c$ except where noted otherwise. All prices include postage.

\section{VERY DARK SHADES}

Othello: (Improved Black Knight) deep $1 \mathrm{oz} .1 / 4 \mathrm{lb} .1 \mathrm{lb}$. maroon and particularly of rich, velvety

effect...................... $\$ .10 \quad 3.20 \quad \$ .50$

Navy Blue : indigo and violet....... $10 \quad .10 \quad .20 \quad .50$

Othello spencer: mammoth maroon, very dark.................... 15 c LAVENDER AND MAUVE, SHADED, PICOTEE OR

Lottle Eckford: white, shaded with lilac, with deeper borde...$\ldots \ldots \ldots \ldots \ldots \ldots$. on white. .............. Pkt., 10c

$\begin{array}{rrr}.10 & .20 & .50 \\ .25 & .60 & 1.25\end{array}$

\section{ORANGE PINK SHADES}

Bolton's Pink: bright pink with orange

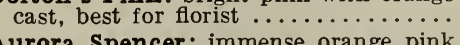
Aurora Spencer: immense orange pink striped on white...........Pkt., 15c A urora: orange-pink and white striped. . Evelyn Byatt: crimson orange self.... Helen Lewis: large wavy orange-pink $\ldots \ldots \ldots \ldots \ldots \ldots$. . . . . . 10

Henry Eckford: almost true orange, self Miss Wilmott: bright orange-pink, showing veins of a deeper tint.......

Miriam Beaver : our grandest noveltya pricot and pink. .......... Pkt., 25c

\section{BRIGHT RED SHADES}

America : red and white striped....... .10

King Edward VII: (Improved Firefly),

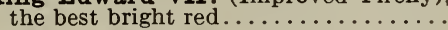

Queen Alexandra: (Improved Scarlet Gem), almost true scarlet...........

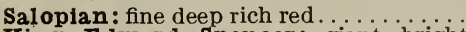

King Edward spencer: giant bright red................ Pkt., 15c

$\begin{array}{lll}.10 & .25 & .60 \\ .10 & .20 & .50 \\ .10 & .25 & .60 \\ .25 & .75 & 2.00 \\ .10 & .25 & .60 \\ .10 & .25 & .60\end{array}$

\section{THE GRANDEST SWEET PEA MIXTURE}

Morse's Superb Mixed: a mixture of the new giant Spencer type of Sweet Peas, with immense wavy petal. This mixture contains several new selections which are not yet named; Pkg., 10c,

\section{SPECIAL COLLECTIONS OF SWEET PEAS}

Our "Incomparable" 25c Collection of Sweet Peas. This package contains one packet each of the following 7 varieties:

King Edward VII: bright red.

Dorothy Eckford: large white.

Prima Donna: fine pink.

Lady Grisel Hamilton: beautiful lavender

Miss Willmot: orange-pink.

Hon. Mrs. E. Kenyon: soft primrose.

Countess spencer: new giant pink.

Our "Excellent" 50c collection of Sweet Peas. This package contains one packet each of the following 12 varieties:

Countess Spencer: mammoth pink

Queen Alexandra: new brilliant scarlet.

Queen Alexandra: new brillian

Dorothy Eckford: large white.

Miss Willmott: large orange-pink.

King Edward VII: giant bright red.

Helen Pierce: blue mottled white.

Hon. Mrs. E. Kenyon: soft primrose.

Phenomenal: giant picotee. edged blue.

Othello: deep maroon.

Navy Biue: violet and blue.

Earliest of All: the earliest,pink and white.

Our "Splendid" $\$ 1.00$ collection of the best Sweet Peas. This package contains one packet each of the following 26 varieties - the newest and best-and 1 packet of Morse's Superb Mixture:

Romolo Piazanni: lilac blue.

Navy Blue: violet and blue.
Pkt $10 \mathrm{c} \$ .25$ \$ $\$ \frac{1 / 4 \mathrm{lb}}{\$ 1 \mathrm{lb}}$

Lord Roseberry: bright rose suffused

with magenta.........................

Prince of Wales : rose-crimson ....... $\quad .10 \quad .20 \quad .50$

Prince of Wales spencer: giant car-

\section{MAUVE AND PURPLE SHADES}

Mrs. Walter Wright (Improved Emily Eckford): light rosy purple, turning blue when fully matured............ Tennant): rosy purple turning blue

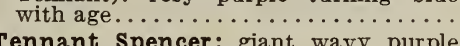
mauve. . ................. pur., 15c

\section{IA VENDER SHADES}

Countess of Radnor: or New Countess linted with mauve....

Asta Ohn Spencer: giant wavy pinkish lavender. .................... 15c

Flora Norton Spencer: wavy, bright blue. .....................

Helen Pierce: bright blue mottled on

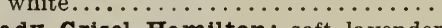
Mrs. Geo. Higginson Jr.: a clear azure IIGHT PINK SHADED

Dainty: white with pink edge.......... lighter pink and delicate flesh at edges Lovely Spencer: deep pink shading to MIXTURES

Best Large Flowering Mixture: this is the best mixture that can be made from existing varieties of the shell-shaped type........................10 .20
King Edward VII: bright red.

Dorothy Eckford: shell-shaped white. Countess Spencer: mammoth pink Lady Grisel Hamilton: soft lavender. Miss Willmott: bright orange-pink. Hon. Mrs. E. Kenyon: large primrose. Phenomenal: giant picotee edged blue. Helen Pierce: blue mottled on white. Aurora: orange-pink striped on white. Queen Alexandra: the new scarlet. Helen Lewis: giant orange and salmon. Shasta: fine large white.

Janet Scott: buff and brilliant pink. Othello: deep maroon.

Lottie Eckford: white, edged with blue.

Earliest of All: the first to bloom, pink and white.

Stella Morse: buff and blush pink.

Mrs. George Higginson Jr.: azure blue.

Morse's Superb Mixture: a mixture of the Countess Spencer type.

Lovely: soft pink with deep throat.

Golden Rose: primrose with soft pink stripes.

Apple Blossom: pink and white.

Lord Roseberry: bright magenta rose.

Florence Morse Spencer: blush white, with pink edge.

White Spencer: the grandest white. 


\section{Sweet Peas-Continued}

Our "Extraordinary Spencer Collection" contains one packet Four of these are our latest novelties, just about to be Four of these are our latest novelties, just about to be
introduced all over America and Europe, and offered here for the first time at retail. There are 24 packets in all. Price.

Apple Blossom Spencer: rose and primrose.

Asta Ohn: lavender and mauve.

Aurora Spencer: salmon or orange-pink, striped and flaked on white.

Beatrice Spencer: rose, pink and buff.

Captain of the Blues spencer: purple and blue.

Countess Spencer: (original), pure bright pink.

Florence Morse Spencer: blush with rose margin.

Flora Norton Spencer: bright blue.

Geo. Herbert: magenta rose.
Felen Lewis: orange pink.

King Edward Spencer: bright red.

Lovely spencer: deep rose shading to blush.

Miriam Beaver: apricot pink.

Mrs. Sankey Spencer: black-seeded white.

Mrs. Routzahn: primrose and blush with rose margin. ,

Primrose Spencer: clear, soft primrose.

Prince of Wales Spencer: carmine rose.

Othello Spencer: deep maroon.

Queen Victoria spencer: black-seeded primrose.

Ramona spencer: white with blush stripes.

Senator Spencer: white with chocolate stripes.

Tennant Spencer: purplish mauve.

W. T. Hutchins: blush and cream.

White Spencer: pure white-seeded white.

\section{Select List of Vegetable Seeds}

\section{FOR FALL AND WINTER PLANTING}

Price per packet 5c except noted otherwise. Prices are post-paid except on peas and onion sets.

If ordered by mail, add 10 cents per pound for postage on Peas and Onion Sets

\begin{tabular}{|c|c|c|c|}
\hline 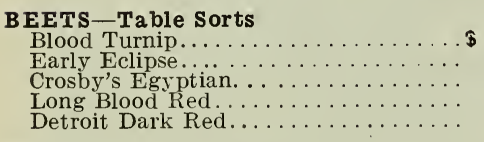 & $\begin{array}{l}\mathrm{Oz} \\
.10 \\
.10 \\
.10 \\
.10 \\
.10\end{array}$ & $\begin{array}{rl}1 / 4 & 1 b \\
\$ \quad .25 \\
.25 \\
.30 \\
.25 \\
.30\end{array}$ & $\begin{array}{l}\text { Lb. } \\
.75 \\
.75 \\
.00 \\
.75 \\
.90\end{array}$ \\
\hline roccoli: large, whit & .40 & 1.25 & 4.00 \\
\hline $\begin{array}{l}\text { RUSSELS SPROUTS } \\
\text { Half Dwarf } \ldots \ldots \ldots \ldots \ldots\end{array}$ & .15 & .45 & 1.50 \\
\hline 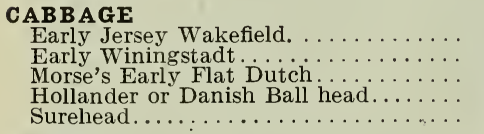 & $\begin{array}{l}.20 \\
.20 \\
.25 \\
.20 \\
.20\end{array}$ & $\begin{array}{l}.60 \\
.60 \\
.75 \\
.00 \\
.60\end{array}$ & $\begin{array}{l}2.00 \\
2.00 \\
2.50 \\
3.50 \\
2.00\end{array}$ \\
\hline $\begin{array}{l}\text { ARROT } \\
\text { Improved Long Orange. } \ldots \ldots \ldots \ldots \ldots \ldots \\
\text { Danver's Half Long..... } \ldots \ldots \ldots \ldots \ldots \ldots \\
\text { Oxheart or Guerande... } \ldots \ldots \ldots \ldots \ldots \ldots \\
\text { Early Scarlet Horn } \ldots \ldots \ldots \ldots \ldots \ldots \ldots \\
\text { Earliest French forcing. } \ldots \ldots \ldots \ldots \ldots \ldots\end{array}$ & $\begin{array}{l}.10 \\
.10 \\
.10 \\
.10 \\
.10\end{array}$ & $\begin{array}{l}.25 \\
.25 \\
.25 \\
.25 \\
.30\end{array}$ & $\begin{array}{r}.75 \\
.90 \\
.85 \\
.85 \\
1.00\end{array}$ \\
\hline 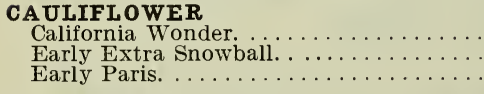 & & $\begin{array}{r}\text { Pkt. } \\
.10 \\
.25 \\
.10\end{array}$ & $\begin{array}{r}\mathrm{Oz} . \\
.75 \\
\mathbf{2 . 5 0} \\
.75\end{array}$ \\
\hline $\begin{array}{l}\text { COLLARDS } \\
\text { True Georgia }\end{array}$ & $\begin{array}{l}\mathrm{Oz} \\
.10\end{array}$ & $\begin{array}{l}1 / 4-1 b \\
\$ \cdot 30\end{array}$ & $\begin{array}{l}\text { Lb. } \\
\$ 1.00\end{array}$ \\
\hline $\begin{array}{l}\text { EEK } \\
\text { Giant Musselburg. }\end{array}$ & .15 & .40 & 1.25 \\
\hline 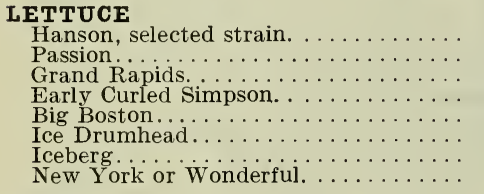 & $\begin{array}{l}.15 \\
.15 \\
.15 \\
.15 \\
.15 \\
.15 \\
.15 \\
.15\end{array}$ & $\begin{array}{l}.4 \\
.4 \\
.4 \\
.4 \\
.4 \\
.4 \\
.4 \\
.4\end{array}$ & $\begin{array}{l}1.50 \\
1.50 \\
1.25 \\
1.25 \\
1.25 \\
1.25 \\
1.25 \\
1.25\end{array}$ \\
\hline 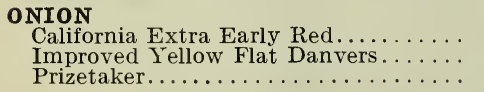 & .15 & & \\
\hline
\end{tabular}

ONIONS

Australian Brown.

Red Wethersfield.

Yellow Globe Danvers.

ONION SETS

Yellow......

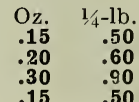

Lb.

2.00

3.00

1.75

White......

$\$$ Lb

.25

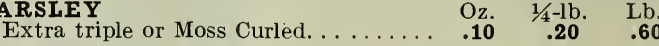

\section{PARSNIP}

Hollow Crown............... $\quad .10 \quad .20$

PEAS

American Wonder. ................\$ $\mathbf{. 1 5}$

Gradus or Prosperity.................. .20

Little Gem..............................

Stratagem..................

Yorkshire Hero.......................15

Champion of England............... .15

Telephone........................

\section{RADISH}

$\mathrm{Oz}$.

Scarlet Turnip white tipped $\ldots \ldots \ldots \ldots \ldots \$ .10$

Early Scarlet Globe.

Improved Chartier.

Long Scarlet

Long White Vienna.

Chinese White Winter.

\section{SALSIFY}

Mammoth Sandwich Island. . . . . . . . . . . $\quad .20 \quad 1.75$

\section{SPINACH}

Thick Leaved...

Lb.

Savoy Leaved ..........................

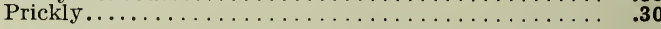

\section{TURNIP}

Early Snowball

Golden Ball

Purple Top Strap Leaf.

White Flat Dutch.

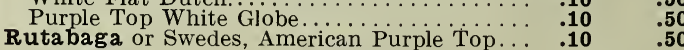

\section{FLOWER SEEDS FOR FALL PLANTING}

Asparagus: Plumosus, Nanus.... (100 seeds)..
Asparagus: Plumosus, Sprengerii. (100 seeds)..

Armeria (Sea Pink).

Columbine: single or double, mixed

Calceolaria: tigered and spotted, mixed.

Calendula: Cape Marigold, fine double mixed. .

Canterbury Bells (Campanula): Cup and Saucer type mixed.

Canterbury Belis: single, mixed

Cineraria: Grandiflora, mixed

Coreopsis: Lanceolata Grandiflora. .

Cyclamen: white or crimson.

Delphinium Formosum: perennial Larkspur, azure blue, or bright blue.................
$\$ .75$ Per pkt.
Daisy (Bellis Perennis): Snowball or Longfellow . . . . $\$$ \$
$\mathbf{1 0 5}$

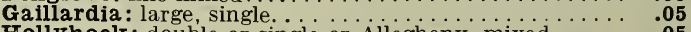
Hollyhock: double or single or Allegheny, mixed.... .05 Mignonette: Golden Queen or Pure Machet or mixed. . $\quad .05$ Pentstemon: fine, $\operatorname{mixed} . \ldots \ldots \ldots \ldots \ldots \ldots \ldots \ldots \ldots . \quad \mathbf{. 1 0}$ Pansies - see page 11 .

Primula Sinensis: choice mixed $\ldots \ldots \ldots \ldots \ldots \ldots \ldots \ldots . .25$

Snapdragon: Giants, mixed..................

weet Peas-see page 12 and 13

Sweet William: single, mixed $\ldots \ldots \ldots \ldots \ldots \ldots \ldots \ldots, \quad .05$

Stocks : Emperor or Perpetual, mixed............ $\quad .10$ 


\section{Lawn Grasses}

All of our Lawn Grasses are from the very best recleaned seed. To make a good lawn the soil cannot be too well prepared. It does not need to be so very rich since a long growth of grass is not so necessary as a thick root growth. Most soil needs, however, some barnyard manure spaded into it, and a covering of half an inch of loam. After it has been well worked it should be watered and allowed to rest two or three weeks so that the weeds can start and be hoed. A second watering and hoeing two weeks later would be well if the time can be spared. The soil should be well rolled before planting the seed since the land needs to be firm and compact. Sow the seed with a sieve if possible, after which cover with a light sprinkling of sandy loam, also put on with a sieve. The seed may, however, be thrown on broadcast and raked in. A lawn may be sown in California any time in the year if there is plenty of water available.

What grass makes the best lawn? This question is often asked us and our experience has shown that for San Francisco and sandy soils Pacific Rye Grass is best for a straight lawn, and our Golden Gate Park Mixture for a mixed lawn. For all other soils Kentucky Blue Grass makes the best straight lawn, and Perennial Rye Grass (preferably the fine-leaved "Pacific Rye") next; while for a good durable summer and winter lawn Morse's California Lawn Mixture has no equal. For extra damp places Morse's Velvet Lawn Mixture is recommended. We also make up special mixtures for shady places which give satisfaction where ordinary grasses will not grow.

One pound of grass seed is required for 250 square feet of lawn. Use half that quantity for renovating old or worn out lawns and apply our Special Lawn Fertilizer, which will greatly invigorate the growth. 10 lbs., 65c; 25 lbs., $\$ 1.25 ; 50$ lbs., $\$ 2.00$.

Pacific Rye Grass: A new lawn grass never before used in California, and sold only by us. It is very vigorous, hardy and long-lived and does well in sandy soils. It is similar to Australian Rye Grass but is much finer leaved and much more long-lived. Per lb., 35c, post paid; by express or freight, per lb., 25c; 10 lbs., $\$ 2.00 ; 100$ lbs., $\$ 17.50$.

Our Golden Gate Park Lawn Mixture: We especially recommend this mixture for those requiring a quick-growing, thick, sturdy lawn which remains green all winter, as well as other seasons of the year; especially for sandy soils. This variety contains a small proportion of white clover, just enough to make it a thick mat. Per lb., 35c, post paid, or by express or freight, lb., 25c; 100 lbs., $\$ 20.00$.

Australian Rye Grass: A very vigorous, quickgrowing lawn grass, but a little coarse. Very satisfactory for lawns in San Francisco. Per lb., 25c, post paid, or by express or freight, 1 lb., 15c; 10 lbs., $\$ 1.50 ; 100$ lbs., $\$ 10.00$.
Morse's California Lawn Mixture: A mixture of more than half a dozen good perennial lawn grasses, all of the heaviest recleaned seed. It gives the very best results in thick, deep green, sturdy lawns which are green both summer and winter. Makes a very satisfactory lawn. Per lb., $45 \mathrm{c}$, post paid, or by express or freight, lb., $35 \mathrm{c} ; 100$ lbs., $\$ 30.00$.

Morse's Velvet Lawn Mixture: A combination of soft, deep green grasses, which form a thick mat especially in the summer. Is easy to cut and easy to grow in good, moist, rich soil, and is especially recommended for adobe soils. Price $45 \mathrm{c}$ per $1 \mathrm{~b}$. post paid, or by express or freight per lb., 35c; 100 lbs., $\$ 30.00$.

White Clover: Of dwarf habit with creeping stems, rooting at the joints, on which account it makes an excellent turf that stands constant tramping. Planted for a lawn either alone or in mixture with grass seed. Price 40 c per lb. post paid, or by express or freight, 30 c per lb.; 100 lbs., $\$ 25.00$.

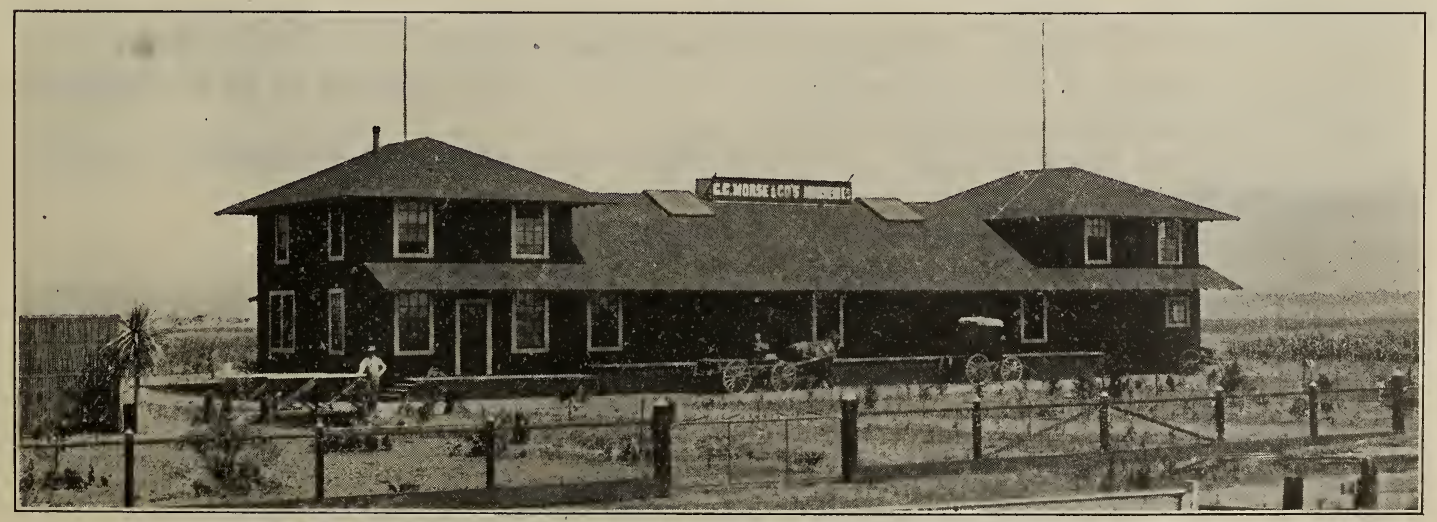




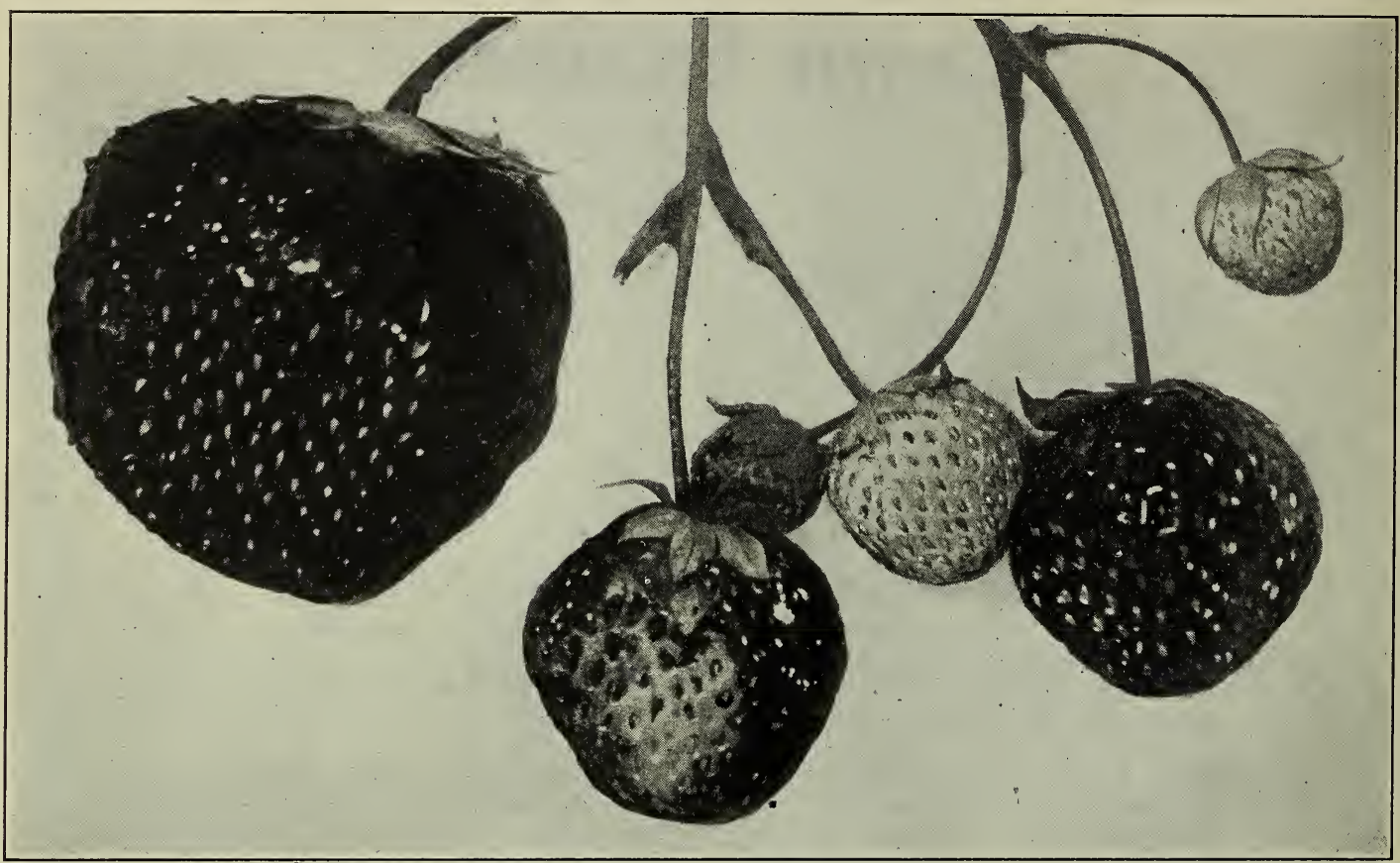

\section{The Morse Strawberry}

A grand-a Superlative Strawberry.

Never Offered to the public before.

Mammoth in size.

Extremely Prolific as a bearer.
Inexpressibly Luscious in flavor.

Deep, Rich Crimson in color.

Bears Continuously for a long season.

The Best Variety ever introduced for the Home Garden.

THE MORSE STRAWBERRY is about as near the perfect strawberry as one can find and is the best novelty of its kind we have ever seen.

THE MORSE STRAWBERRY is a large, deep crimson, solid berry, deep crimison clear to the core, and of the best real strawberry flavor one can imagine.

THE IMORSE STRAWBERRY begins to bear early and bears profusely and for a long period.

THE MIORSE STRAWBERRY usually so large that one naturally slices it into quarters when eating.

THE MORSE STRAWBERRY is never hollow and pithy, but always solid and meaty and juicy. The plants are ready, and autumn is the time to plant.

To any one with the land and some water, we recommend this greatest of all strawberries, and urge you to send to us for some plants at once.

Price: per dozen, $\$ 1.00$, postpaid; per $50, \$ 3.00$, postpaid $\$ 3.25$; per $100, \$ 5.00$, by express.

\section{Nursery Department}

In our 1910 catalogue will be found a full list of Nursery Stock grown by us. Our greenhouses and salesyard are situated on Glen Avenue near the terminus of the Key Route, Piedmont Avenue, Oakland, and our nurseries at Livermore.

We have recently purchased a tract of land near Haywards, Alameda County, and erected buildings, lath sheds, etc. From this place in the future we will carry on our nursery business.

Those in need of nursery stock will do well to write us for our 1910 catalogue, as it is full of interest. 


\section{ORDER Plant and Tree sHEET \\ C. C. MORSE \& CO.}

Retail Store

125-127 MARKET STREET

Ofice and Warehowse

SAN FRANCISCO, CALIFORNIA.

Date,

Enclosed find \$

Name

Post Office.

Street Address or

No. Rural Delinery

County

State.

Forward this order by

On Plant Orders please add 10\% for packing to cover actual cost of material. All orders for Trees and Plants will be shipped from our nurseries in Oakland.

\section{ORDER SEED SHEET C. C. MORSE \& Co.}

Retail Store

125-127 MARKET STREET

Orilce and Warehouse

SAN FRANCISCO, CALIFORNIA.

Date

190

Enclosed find \$

Name.

Post Office

Street Address or

No. Rural Delivery

County

State

Forward this order by

VERY IMPORTANT-No matter how often you write us, always be careful to give full name and address. Write name very plainly. State how to forward-whether by freight, express or mail.

\section{SEEDS POSTPAID BY MAIL}

We mail and pay postage on all seeds in PACKETS, OUNCES and $1 / 4$ POUNDS purchased from this Catalogue. On larger quantities add 100 per pound to Cata logue prices for postage. 
SPECIAL NOTICE: We shall esteem it a great favor if you will give us below the NAMES and ADDRESSES of any of your friends that are interested in gardening. We wish to send them our CATALOGUE.

$$
\text { NAME }
$$

POST OFFICE

STATE
SPECIAL NOTICE:

We shall esteem it a greal favor if you will give us below the send them our CATALOGUE. 
From

P. 0 . State

C. C. MORSE \& CO., arowers SEEDS Desaters. SAN FRANCISCO, 



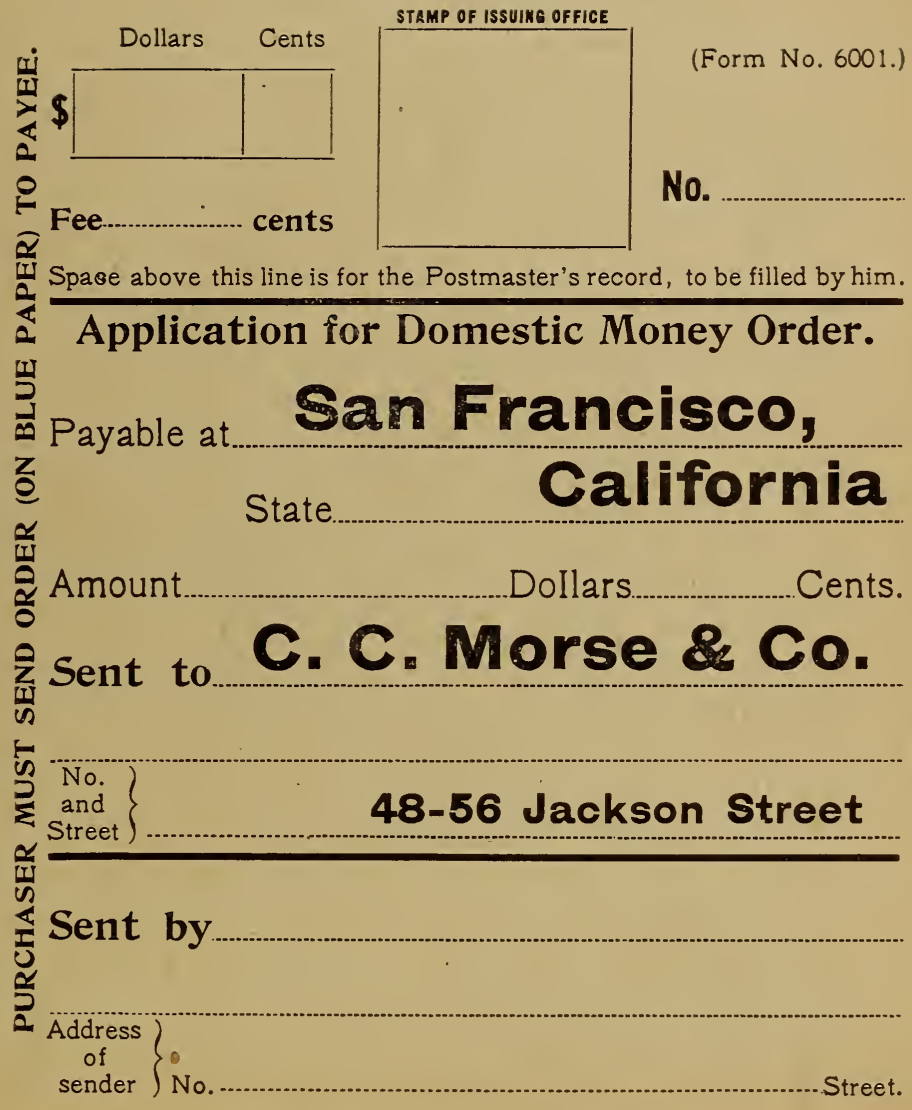




\section{Fees for Domestic Money Orders}

Payable in the United States (which includes Hawaii and Porto Rico) and its possessions comprising the Canal Zone (Isthmus of Panama), Guam, the Philippines and Tutuila, Samoa: also for Orders payable in British Guiana, British Honduras, Canada, Cuba, Newfoundland, the United States Postal Agency at Shanghai (China), the Bahama Islands and certain other Islands in the West Indies mentioned in Register of Money Order Post Offices.

\begin{tabular}{|c|c|c|}
\hline For Orders & $\begin{array}{l}\text { From } \$ 0.01 \text { to } \$ 2.50 \\
\text { From } \$ 2.51 \text { to } \$ 5.00 \\
\text { From } \$ 5.01 \text { to } \$ 10.00 \\
\text { From } \$ 10.01 \text { to } \$ 20.00 \\
\text { From } \$ 20.01 \text { to } \$ 30.00 \\
\text { From } \$ 30.01 \text { to } \$ 40.00 \\
\text { From } \$ 40.01 \text { to } \$ 50.00 \\
\text { From } \$ 50.01 \text { to } \$ 60.00 \\
\text { From } \$ 60.01 \text { to } \$ 75.00 \\
\text { From } \$ 75.01 \text { to } \$ 100.00\end{array}$ & $\begin{array}{l}\ldots \ldots .3 \text { cents. } \\
\ldots \ldots .5 \text { cents. } \\
\ldots \ldots .8 \text { cents. } \\
\ldots \ldots 10 \text { cents. } \\
\ldots \ldots 12 \text { cents. } \\
\ldots \ldots 15 \text { cents. } \\
\ldots \ldots 18 \text { cents. } \\
\ldots \ldots 20 \text { cents. } \\
\ldots \ldots 25 \text { cents. }\end{array}$ \\
\hline
\end{tabular}

\section{Memoranda of Issuing Postmaster:}

NOTE-The Maximum amount for which a single Money Order may be issued is $\$ 100$. When a larger sum is to be sent additional Orders must be obtaiued. Any number of Orders may be drawn on any Money Order office; but. if Orders are drawn in excess of $\$ 200$ on any one day upon an office of the 4th class, notice of the fact by letter [or Form 6037] is to be promptly sent the Department by the issuing Postmaster so that provision may be made for payment.

Applications must be preserved at the office of issue for four years from ate of issue.

[EDITION FEB., 1907.] 


\section{"Morse's Special Tulips" for California}

After studying the special conditions on the Pacific Coast for several years, we have finally discovered the race of Tulips which thrives in our gardens here. These we have called "Morse's Special Tulips" and recommend them for all out-of-door planting. These Tulips have long stems, and bright colors (except the Darwin class which has dark, rich colorings). They flower in April. Enrich the soil for best results. Plant a bed of fifty or more; they are worth it. Our list of these Tulips is the largest that there is and our stock is the best. (Postage 5c per doz. additional).

\section{Single}

Gesneriana Major: the most brilliant and dazzling crimson with

Per doz. Per 100 black center. Has fine large blossoms with long stems. Always

does well when planted outside and is tremendously handsome

Iorse's stock of this is superior.

Beauty of America: cream changing to pink

$\$ \quad .35 \quad \$ 2.25$

Bridesmaid: cherry, pink, striped scarlet and

$40 \quad 2.75$

Bouton D'Or: pure golden yellow, globe-shaped flowers, very long stems. .

$.35 \quad 2.25$

Caledonia: orange scarlet, greenish black center, fine bold flower

Fulgens: brilliant crimson, creamy white center, reflex petals, long stems about 24 inches.

Gesneriana Spathulata: or Crimson, see Gesneriana Major above.

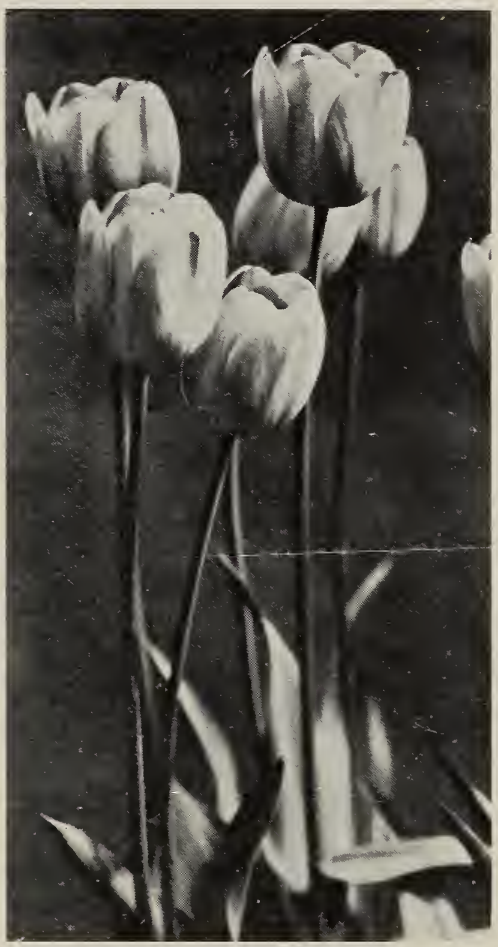

\section{Per doz. Per 100}

Gesneriana Aurantiaca: orange-red tulip of

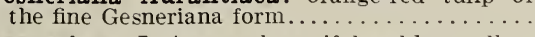

Gesneriana Lutea: a beautiful golden yellow Gesneriana Tulip-large flowers with long stems. .

Gesneriana Rosea: rosy carmine with black center, long stems..

Golden Crown: large golden yellow-splendid. Golden Eagle: bright golden yellow-handsome

Isabella or Blushing Bride: creamy white and pink, changing darker rose center, marked peacock blue.

La Merveille: a large tulip of a striking color, being salmony-rose overlaid with orange-red.

La Reeve: large handsome flowers of a rosy-buff tone with yellow base. (Received an Award of Merit.)

Macrospila: sweet scented, large crimson scarlet,

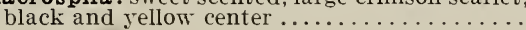

$\$ .40 \$ 3.00$

$.75 \quad 5.00$

$.40 \quad 2.50$

$.30 \quad 2.00$

$.30 \quad 2.00$

$.40 \quad 2.75$

$.40 \quad 3.00$

$.75 \quad 6.00$

$.30 \quad 2.00$
Per doz. Per 100

Maiden's Blush: pure white, margined rose...\$ $\mathbf{. 3 0} \$ \mathbf{\$ 2 . 0 0}$ Marriage de ma Fille: double late flowering,

white, feathered with crimson, very large

flowers. ...........

$.60 \quad 4.00$

Mrs. Moon: an immense Tulip of a rich orange

rellow ................. 12.50

Striped Beauty: rose color, flaked deep crimson $\begin{array}{r}.50 \\ 4.00\end{array}$

and white................................. $\quad .50$

Royal White: beautiful globular shaped white $\mathbf{1 . 1 5} \mathbf{9 . 0 0}$

Viridiflora: the Green Tulip, edged yellow;

6ceach. collection, 2 each of above sorts (40 bulbs)

$\$ 1.50$

\section{DARWIN TULIPS}

This is the rariety illustrated on the outside of the bach cover. (See page 4. .)

Named Varieties.

Per doz. Per 100

$\$ .90 \$ 6.50$

Iixed Darwins.

\section{"Morse's Special Mixed"}

Late Mixed Tulips, made up by ourselves from named varieties, embraces all classes late sorts: nothing so fine elsewhere; 35c per doz.; \$2.00 per 100.

\section{Our General or Annual Catalogue for 1910}

Will be ready to mail early in December. It will be handsome and comprehensive and gives full directions for planting. We list a very large assortment of all the best Garden Seed, Flower Seed, Clovers, Grasses, Horticultural Tools, Insecticides, etc.

If you have not ordered anything of us recently we are not likely to have your name on our mailing list and would suggest that you send us your name and address at once, and this handsome catalogue will gladly be sent to you free of cost. 


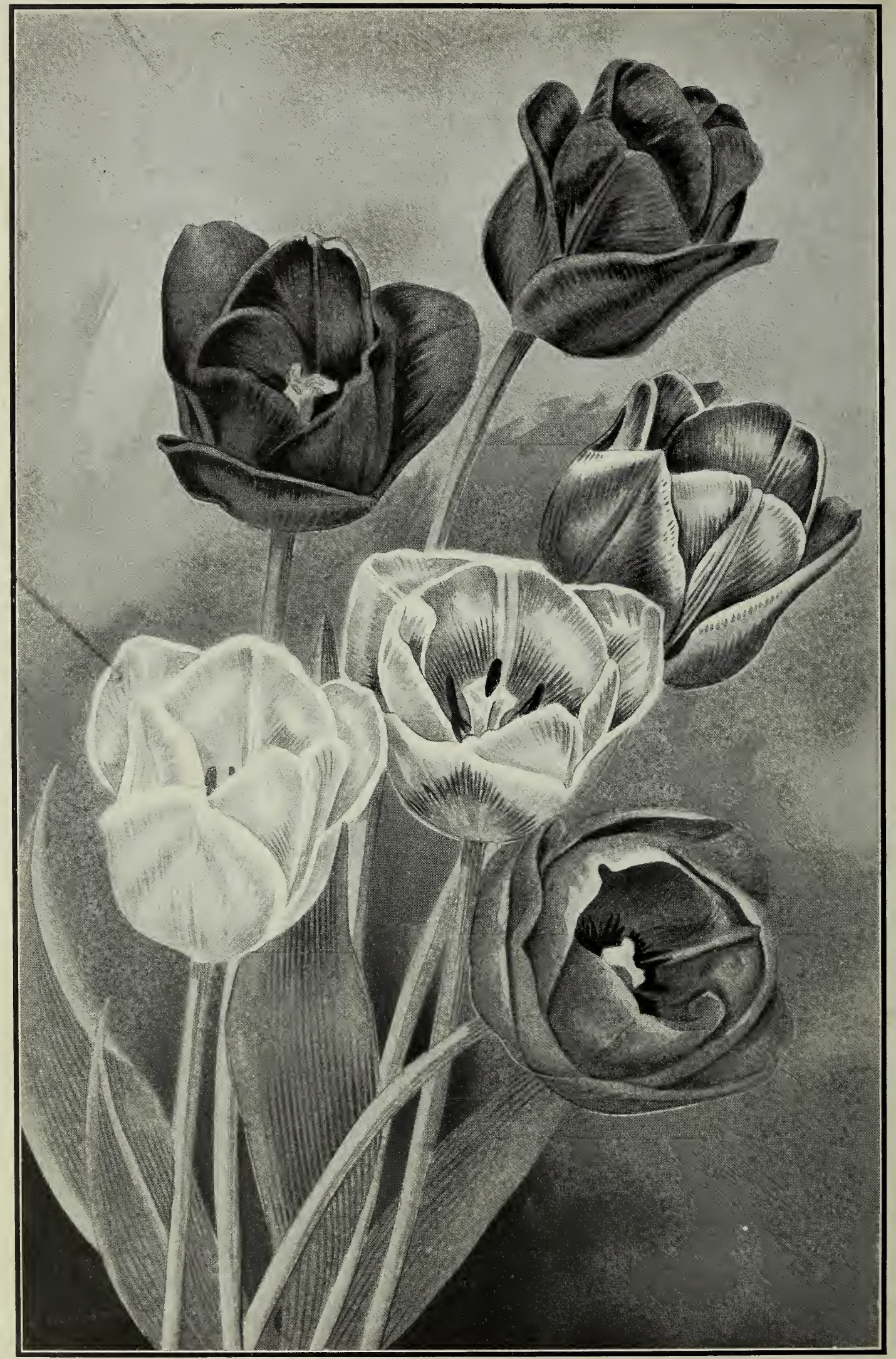

IMorse's Special Tulips for California 